
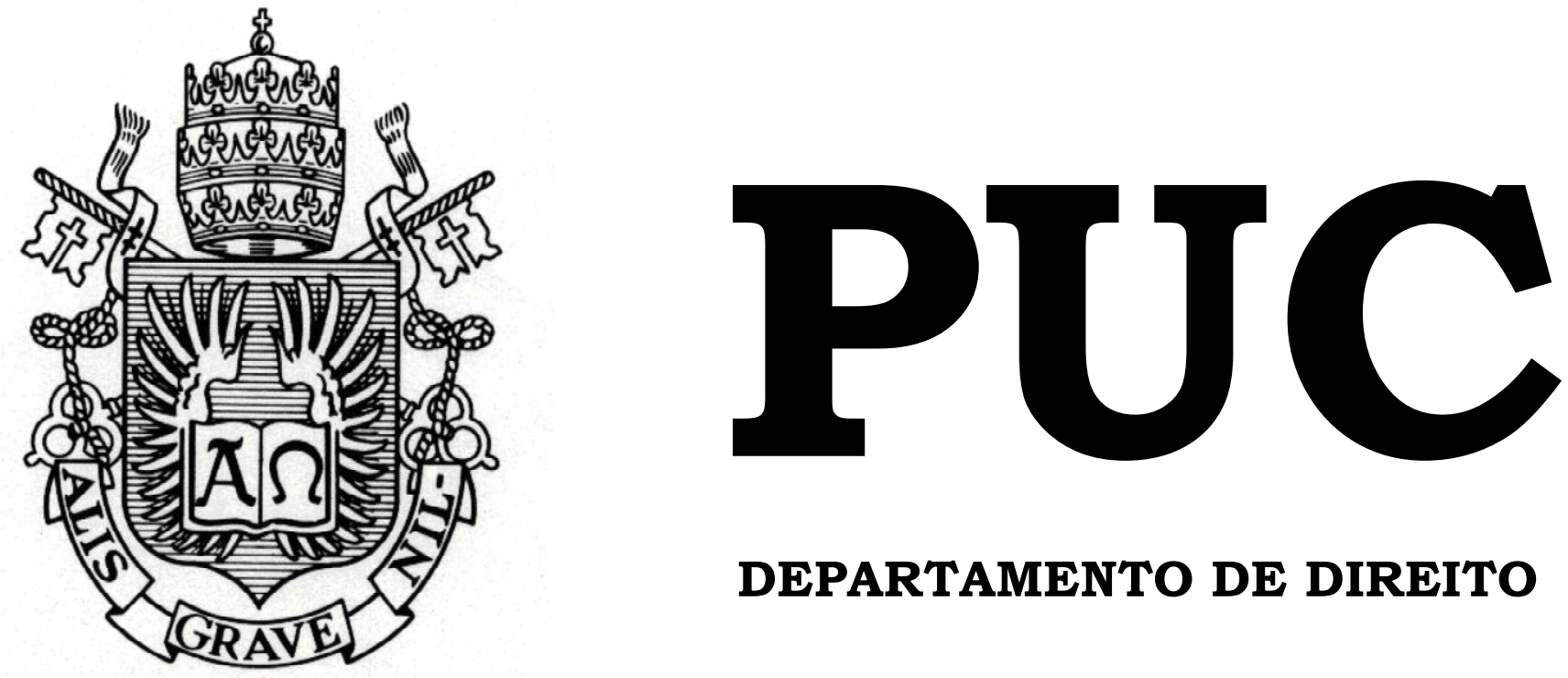

DEPARTAMENTO DE DIREITO

\title{
RESOLUÇÃO DE CONTRATOS POR \\ INCUMPRIMENTO PARCIAL \\ OU DEFEITUOSO DO DEVEDOR
}

por

JOÃO FELIPE VIANNA MARTINS DE ALMEIDA

ORIENTADOR: Prof. Lauro Gama Jr.

2015.1

PONTIFÍCIA UNIVERSIDADE CATÓLICA DO RIO DE

JANEIRO RUA MARQUÊS DE SÃO VICENTE, 225 - CEP

22453-900

RIO DE JANEIRO - BRASIL 


\title{
RESOLUÇÃO DE CONTRATOS POR INCUMPRIMENTO PARCIAL OU DEFEITUOSO DO DEVEDOR
}

\author{
por
}

\section{JOÃO FELIPE VIANNA MARTINS DE ALMEIDA}

Monografia apresentada ao Departamento de Direito da Pontificia Universidade Católica do Rio de Janeiro (PUC-Rio) para a obtenção do Título de Bacharel em Direito.

Orientador: Prof. Lauro Gama Jr. 


\section{AGRADECIMENTOS}

Ao final da graduação, posso dizer que a escolha da PUC-Rio para me formar em Direito foi mais do que acertada. Na faculdade, tive a oportunidade de ter aulas com professores excelentes, além de formar amizades para o resto da vida. Participei, também, do Grupo de Estudos em Arbitragem e Direito do Comércio Internacional (GEADICI), com o qual competi no Willem C. Vis International Commercial Arbitration Moot, certamente a experiência mais enriquecedora que um aluno de Direito em qualquer lugar do mundo pode ter.

Agradeço, portanto, àqueles que fizeram parte dessa jornada na PUC-Rio, em especial, Victor Vieira, Nastassja Chalub, Luiz Felipe França, Isabela Blotta, Bernardo Machado e Natasha Vilela. A todos os membros do GEADICI e ao meu orientador Lauro Gama, agradeço por todos os ensinamentos e excelente companhia na missão de representar a nossa querida faculdade.

Na PUC-Rio, tive, ainda, a honra de ter aula com o Marcelo Ferro e o José Roberto de Castro Neves, com os quais hoje tenho o prazer de trabalhar. Absorver as lições diárias de ambos, bem como as do Marcos Pitanga, Pedro Ivo Bobsin e Gustavo Birenbaum, é um privilégio de que me orgulho imensamente, conquistado com muito suor e dedicação. Essa jornada, no entanto, está apenas começando.

No meu primeiro estágio tive a oportunidade de conhecer a Michele Leite, símbolo de carinho e conhecimento, com quem vivi os momentos mais felizes da minha vida. A ela, agradeço por todo o apoio e afeto e por tudo que ainda virá pela frente.

Agradeço, também, aos amigos eternos feitos na minha segunda casa, a Escola Alemã Corcovado, pela compreensão da minha ausência nos últimos anos, sendo certo que são a família que eu escolhi. 
Por fim, e, nesse caso, mais importante, a conclusão da graduação não seria possível sem a fundamental ajuda e apoio incondicional dos meus pais, Gustavo e Denise, além da minha irmã, Ana Clara, a quem eu devo tudo o que sou. 
"A disciplina é a ponte que liga nossos sonhos às nossas realizações".

Pat Tillman 


\section{LISTA DE ABREVIATURAS}

CC - Código Civil de 2002

CISG - Convention on Contracts for the International Sale of Goods

CJF - Conselho da Justiça Federal

REsp - Recurso Especial

STJ - Superior Tribunal de Justiça

TJSP - Tribunal de Justiça do Estado de São Paulo

ULF - Convenção para Lei Uniforme sobre a Formação dos Contratos de Compra e Venda Internacional

ULIS - Convenção para Lei Uniforme relativa a Compra e Venda Internacional

UNCITRAL - United Nations Commission on International Trade Law

UNIDROIT - International Institute for the Unification of Private Law 
A presente monografia tem como objeto o estudo do instituto da resolução contratual por incumprimento parcial ou defeituoso do devedor. A partir de uma análise histórica da criação do instituto, busca-se entender os seus fundamentos e os efeitos causados pela sua aplicação para as partes e para a sociedade como um todo. Ao final, é feita uma análise do instituto à luz da Convention on Contracts for the International Sale of Goods ("CISG"), recentemente incorporada ao direito brasileiro.

Para o melhor entendimento sobre a aplicação do instituto, é feita uma distinção com outras figuras análogas, fugindo da confusão terminológica causada pela existência de diversos institutos semelhantes.

Delimitado o tema, segue-se uma análise da sua aplicação no Brasil, considerando a infelicidade do legislador ao facultar ao credor a resolução em caso de inadimplemento do devedor, sem, no entanto, especificar quais hipóteses de inadimplemento autorizam a resolução contratual.

Procura-se, portanto, demarcar os critérios balizadores para a resolução do contrato em caso de incumprimento parcial ou defeituoso, sobretudo considerando os princípios da boa-fé objetiva e da função social do contrato.

\section{PALAVRAS-CHAVE}

Direito Civil. Resolução Contratual. Extinção de Contratos. Direito das Obrigações. Código Civil. Convenção de Viena de Compra e Venda Internacional de Mercadorias. 



\section{SUMÁRIO}

Página

Introdução

Capítulo 1 - Importância e Delimitação do Conceito de

Resolução

Consequências Jurídicas e Econômicas da Resolução

Contratual

1.2

Delimitação do conceito de Resolução e Figuras Afins

1.3 Espécies de Resolução

$2.1 \quad$ Direito Romano

2.2 Direito Feudal e Canônico

2.3 O Sistema Francês

$2.4 \quad$ O Sistema Alemão 
3.2 Limitações à Resolução Contratual 30

3.3 Efeitos da Resolução Contratual 38

Capítulo 3 - Resolução de Contratos na Convenção de 43

Comércio Internacional de Mercadorias - CISG

4.1 Histórico da Convenção 43

4.2 Estrutura e Princípios da CISG 45

4.3 Resolução de Contratos na CISG 48

4.4 A Declaração de Resolução e os Efeitos para as Partes 52

$\begin{array}{ll}\text { Conclusão } & 55\end{array}$

$\begin{array}{ll}\text { Bibliografia } & 57\end{array}$ 


\section{Introdução}

Celebramos diversos contratos todos os dias. Por exemplo, ao entrar em um táxi a caminho do trabalho nos comprometemos a pagar ao motorista em contraprestação pelo transporte ao destino desejado. Ao mesmo tempo, em outro lugar do mundo, uma empresa chinesa celebra contrato de compra e venda de toneladas de soja com uma empresa brasileira envolvendo milhões de reais e o trabalho de milhares de pessoas.

Esses e outros tantos contratos, aparentemente distintos em suas classificações e tipologia, têm em comum a vontade das partes em obter o seu adimplemento integral. Contudo, boa parcela dos contratos firmados no cotidiano não é cumprida da maneira prevista pelas partes no momento da sua celebração. Os motivos são inúmeros. No presente trabalho, será analisada a hipótese de incumprimento contratual por uma das partes em virtude de um motivo ou conduta imputável a ela, ou a terceiro sob sua responsabilidade.

Nesses casos, a parte inadimplente deverá indenizar a contraparte pelas perdas e danos gerados pelo cumprimento defeituoso da sua obrigação ou, o que é mais grave, seu incumprimento definitivo. Nas hipóteses em que a prestação se tornou impossível por culpa de uma das partes, não tendo sido prestada qualquer parcela da prestação contratada, faculta-se a resolução do contrato à contraparte adimplente.

Há, no entanto, incerteza quanto à possibilidade de resolução contratual nos casos em que a obrigação é cumprida de forma defeituosa, seja na forma, modo ou tempo. A presente monografia tem como objetivo analisar os critérios determinantes da faculdade de resolução do contrato pela parte adimplente nos casos em que ocorre incumprimento parcial ou defeituoso, na busca pelo parâmetro mais adequado aos princípios contratuais que regem o direito pátrio e o comércio internacional. 
O trabalho começa com a demonstração da importância prática do tema no contexto jurídico e econômico, em virtude das consequências da opção legislativa quanto ao seu regramento. Em seguida, o instituto será diferenciado de figuras semelhantes, como a rescisão, a resilição e o distrato. Posteriormente, serão demonstradas as espécies de resolução previstas no ordenamento brasileiro e as suas diferenças.

Após a delimitação do tema, no capítulo 2 será feita uma breve incursão na gênese do direito à resolução dos contratos no direito canônico e feudal, bem como os motivos pelos quais tal faculdade não era prevista ao lesado no direito romano. Em seguida, serão analisados os regramentos modernos do instituto, com notável diferença entre o sistema francês e o sistema alemão. O Código Napoleão e o Bürgeliches Gesetz Buch ("BGB") são apontados como base do regramento da grande maioria dos sistemas contratuais ao redor do mundo e contêm importante divergência. A sua redação foi inspirada em doutrinadores nacionais, no entanto, discute-se se os legisladores daqueles países registraram as suas lições da maneira correta.

Posteriormente, no capítulo 3, será feito um histórico do instituto no direito brasileiro, com enfoque no seu regramento no Código Bevilaqua e, mais recentemente, no Código Civil de 2002. A influência do sistema francês e a sua diferença em relação ao regramento no direito brasileiro tambêm serão objeto de estudo, com enfoque nas consequências práticas e econômicas.

Em sequência, serão discutidos os limites ao direito à resolução contratual, considerando os princípios contratuais insculpidos no Código Civil vigente, notadamente a função social do contrato e a boa-fé objetiva. O princípio da conservação dos contratos também merecerá análise, como método de interpretação norteador, em virtude dos nefastos efeitos da resolução contratual para as partes e para a economia como um todo.

O último capítulo abordará o inadimplemento contratual sob a ótica da Convenção de Viena sobre a Compra e Venda Internacional de Mercadorias 
(CISG). Inicialmente será feita uma breve exposição sobre as tratativas que antecederam a redação da convenção e a sua finalidade no âmbito do comércio internacional.

Após, serão expostos os princípios basilares da CISG e a sua compatibilidade com o ordenamento pátrio. Em seguida, serão analisadas as possibilidades de resolução de contratos de comércio internacional regulados pela CISG, sempre com o objetivo de traçar um paralelo com as regras do direito brasileiro. 


\section{Capítulo 1 - Importância e Delimitação do Tema}

\subsection{Consequências Jurídicas e Econômicas da Resolução Contratual}

Os principais efeitos da resolução contratual são (i) a liberação das partes das obrigações contraídas anteriormente e (ii) a necessidade de restituir ${ }^{1}$ tudo o que receberam em virtude do contrato extinto ${ }^{2}$. O retorno ao status quo ante retira, ainda, a eficácia dos atos produzidos em virtude da relação obrigacional formada entre as partes ${ }^{3}$, ressalvado o direito de terceiros de boa-fé.

A opção de resolução funciona para as partes como um direito formativo extintivo $^{4}$ do contrato, persistindo a relação obrigacional global em relação aos deveres secundários, tais como o de indenização pelas perdas e danos e restituição do que as partes obtiveram por consequência daquela avença ${ }^{5}$.

Tal raciocínio vai ao encontro da visão da relação obrigacional como um processo $^{6}$. Se o adimplemento perfeito tem como consequência o equilíbrio contratual e a cessação das obrigações contratuais ${ }^{7}$, o inadimplemento capaz de

\footnotetext{
${ }^{1}$ PONTES DE MIRANDA. Tratado de Direito Privado. $4^{\text {a }}$ ed., São Paulo: Borsoi, 1959. t. 25, p. 349; DIREITO, Carlos Gustavo Vianna, Do Contrato - Teoria Geral. Rio de Janeiro: Renovar, 2007, p. 204. A necessidade de restituir advém do fundamento do direito à resolução. Segundo a doutrina argentina, a origem seria a necessidade de correspectividade ou equilíbrio das prestações: "La resolución es um modo extinctivo que tiene su fundamento em la correspectivida de las prestaciones." LORENZETTI, Ricardo Luis. Tratado de Los Contratos - Parte General. $2^{\mathrm{a}}$ ed., Buenos Aires: Rubinzal - Culzoni Editores, 2010, p. 580. No mesmo sentido, GRAND, Julio Conte, La Extinción de La Relación Contractual, in. Contratos Civiles y Comerciales, Coord. TARTIÈRE, Gabriel de Reina., Buenos Aires: Heliasta, 2010, p. 370 . No Brasil, várias teorias foram aventadas, dentre elas as da condição implícita, da causa, da sanção, do poder dispositivo e, por fim e mais recentemente, a da equidade, que parece se coadunar com o princípio da correspectividade acima mencionado. Nesse sentido, LOUREIRO, Francisco Eduardo. Extinção dos Contratos, in. Teoria Geral dos Contratos, São Paulo: Atlas, 2011, pp. 626/627, coord. LOTUFO, Renan e NANNI, Giovanni Ettore

${ }^{2}$ AGUIAR JÚNIOR, Ruy Rosado de. Extinção dos contratos por incumprimento do devedor: resolução: de acordo com o novo Código civil. $2^{\mathrm{a}}$ ed. Rio de Janeiro: AIDE, 2003. p. 257

${ }^{3}$ PONTES DE MIRANDA. Tratado de Direito Privado. $4^{a}$ ed., São Paulo: Borsoi, 1959. t. 25, p. 282

${ }^{4}$ AGUIAR JÚNIOR, Ruy Rosado de. Extinção dos contratos por incumprimento do devedor: resolução: de acordo com o novo Código civil. $2^{\mathrm{a}}$ ed. Rio de Janeiro: AIDE, 2003. p. 21

${ }^{5}$ LARENZ, Karl. Derecho de Obligaciones, Madri: Revista de Derecho Privado - Editorial, 1958, p. 394

${ }^{6}$ COUTO E SILVA, Clovis do. A Obrigação como Processo, Editora FGV, 2006

${ }^{7}$ Salvo as obrigações pós-contratuais, como, por exemplo, o dever de sigilo em caso de cláusula de confidencialidade e o dever de cooperação.
} 
gerar a resolução do contrato tem como consequência a necessidade de se refazer o equilíbrio por via oblíqua, de modo a evitar o enriquecimento sem causa de uma das partes.

Na doutrina brasileira, Clóvis do Couto e Silva tratou da obrigação como um processo que se finda com o adimplemento da prestação. A doutrina alemã, no entanto, identificou a subsistência da relação obrigacional mesmo no caso de inadimplemento, o que gera a chamada relação de liquidação entre as partes, conforme se extrai da seguinte passagem da obra de Karl Larenz:

\begin{abstract}
"La relación de liquidación o extinción - Cuando uma vez declarado el desistimiento se origina después la pretensión a la restitución, y el obligado a èsta impossibilita el cumpliumiento de su deber de restituir por uma conducta suya de que es responsable, su obligación se concretará entonces según los preceptos generales de la indemnización de daños."
\end{abstract}

A consequência prática da volta ao estado anterior, no entanto, é, via de regra, extremamente penosa para as partes e, de forma indireta, para toda a sociedade. $\mathrm{O}$ desfazimento do contrato torna sem efeito todos os atos realizados até então, levando à completa frustração das expectativas dos contratantes ao firmarem o pacto resolvido.

A transferência transferência de bens e contratação serviços que movimentam a economia é desfeita, o que acarreta para o contrato antes firmado um resultado extremamente negativo, não só por não ter efeito econômico proveitoso para nenhuma das partes, como pelas consequências nefastas que o seu desfazimento pode acarretar para os contratantes e, indiretamente, a terceiros que poderiam se beneficiar daquele contrato firmado.

Por esses motivos, o legislador criou diversos métodos para que o contrato subsista", mesmo que eivado de nulidade relativa ("utile per inutile non

\footnotetext{
${ }^{8}$ LARENZ, Karl. Derecho de Obligaciones, Madri: Revista de Derecho Privado - Editorial, 1958, p. 394

${ }^{9}$ Por exemplo nos casos de conservação dos contratos em caso de nulidade relativa, como previsto nos arts. 155 e $157, \S 2^{\circ}$
} 
vitiatur "10). Em relação à resolução contratual por inadimplemento sem cláusula expressa, a interpretação judicial deve ser realizada considerando o princípio da conservação dos contratos, decretando-se a resolução apenas no caso de perda do interesse do credor $^{11}$ ou incumprimento definitivo ${ }^{12}$. No caso de incumprimento parcial, o devedor suprirá a sua falta com indenização por perdas e danos, sendo a resolução considerada a ultima ratio em virtude das consequências acima narradas.

No âmbito do comércio internacional de mercadorias, conforme se verá em capítulo próprio, a necessidade de conservação dos contratos é ainda mais refulgente. Com efeito, a restituição de mercadorias, muitas vezes enviadas em enorme quantidade e com alto custo de transporte para outro continente, é praticamente inviável, principalmente quando se trata de bens perecíveis.

Conforme visto, a principal consequência jurídica da resolução contratual é o retorno ao status anterior e, para tanto, é necessária a restituição de tudo o que foi recebido em função do contrato resolvido. A consequência econômica é a ausência de vantagem das partes com o negócio jurídico desfeito e o seu encargo em desfazer o que já havia sido realizado, resultando, portanto, em um saldo negativo. $\mathrm{O}$ assunto será retomado no item 3.3, em que serão analisados os efeitos da resolução contratual.

\subsection{Delimitação do Tema e Figuras Afins ${ }^{13}$}

Há, no cotidiano jurídico, enorme imprecisão no emprego dos termos designados para diferentes hipóteses de desconstituição de dívidas. Ao

\footnotetext{
${ }^{10}$ MAXIMILIANO, Carlos. Hermenêutica e Aplicação do Direito, $6^{\text {a }}$ ed., Rio de Janeiro: Forense, 1979, p. 260

${ }^{11}$ Conforme o art. 395, p. ún do Código Civil: "Se a prestação, devido à mora, se tornar inútil ao credor, este poderá enjeitá-la, e exigir a satisfação das perdas e danos"

12 AGUIAR JÚNIOR, Ruy Rosado de. Extinção dos contratos por incumprimento do devedor: resolução: de acordo com o novo Código civil. $2^{\mathrm{a}}$ ed. Rio de Janeiro: AIDE, 2003. p. 96

${ }_{13}$ Para uma distinção sintética, porém extremamente clara, ver: WALD, Arnoldo. Obrigações $e$ Contratos. $17^{\mathrm{a}}$ ed., Rio de Janeiro: Saraiva, 2006, pp. 324/328
} 
conceituar o distrato, uma das figuras semelhantes, porém com consequências distintas da resolução, Pontes de Miranda expressa irritação com a imprecisão dos termos utilizados:

"Se há matéria, no direito das obrigações, em que se faz urgente limpar-se a linguagem de erros e ambiguidades lastimáveis, é a respeito dos modos de desconstituição das dívidas. Às línguas latinas tem faltado o rigor necessário e os tradutores de livros alemães chegam a verdadeiros atentados. No fundo, são professores e juristas que não sabem distinguir revogar, resolver, resilir, denunciar, rescindir e distratar." 14

Cumpre realizar, portanto, breve distinção entre a resolução contratual e algumas figuras semelhantes. Primeiramente, a resolução se distingue da rescisão, pois a última é utilizada para extinguir obrigações em virtude de vícios existentes no momento da formação do contrato $^{15}$, enquanto aquela é consequência de um fato posterior à celebração da avença (incumprimento ou onerosidade excessiva) ${ }^{16}$.

Conceito igualmente distinto é o do distrato, que consiste em um "negócio jurídico bilateral com fim extintivo, em que se exercitam manifestações de vontade para a desconstituição da eficácia do contrato" ${ }^{17}$. O distrato, portanto, ocorre em comum acordo, pois a subsistência do negócio jurídico celebrado entre as partes não é mais do interesse dos contratantes.

Há, ainda, o arrependimento, caso em que a parte contratante desiste do contrato. Nessa hipótese, a parte perderá as arras dadas ou as devolverá em dobro $^{18}$.

\footnotetext{
${ }^{14}$ PONTES DE MIRANDA. Tratado de Direito Privado. $4^{\mathrm{a}}$ ed., São Paulo: Borsoi, 1959. t. 25, p. 281

15 AGUIAR JÚNIOR, Ruy Rosado de. Extinção dos contratos por incumprimento do devedor: resolução: de acordo com o novo Código civil. $2^{\mathrm{a}}$ ed. Rio de Janeiro: AIDE, 2003. p. 70

16 TEPEDINO, Gustavo; BARBOZA, Heloisa Helena; BODIN DE MORAES, Maria Celina, org. Código Civil Interpretado Conforme a Constituição da República. Rio de Janeiro: Renovar, 2012, p. 122

17 AGUIAR JÚNIOR, Ruy Rosado de. Extinção dos contratos por incumprimento do devedor: resolução: de acordo com o novo Código civil. $2^{\mathrm{a}}$ ed. Rio de Janeiro: AIDE, 2003. p. 71

18 AGUIAR JÚNIOR, Ruy Rosado de. Extinção dos contratos por incumprimento do devedor: resolução: de acordo com o novo Código civil. $2^{\mathrm{a}}$ ed. Rio de Janeiro: AIDE, 2003. p. 71
} 
Figura igualmente semelhante, porém, com consequências distintas, é a revogação. O que se revoga não é o contrato, mas sim a manifestação da vontade de contratar ${ }^{19}$. Após a formação do contrato, com o acordo de vontades consubstanciado pela aceitação da proposta pelo oblato, não é dado mais ao proponente revogar a proposta, salvo nos casos previstos em lei.

Outro instituto semelhante é o da extinção do contrato por força de lei, que ocorre automaticamente se verificada a condição prevista no ordenamento. Tal possibilidade é prevista, no Código Civil, nos arts. 234, 238, 248 e 25020.

A denúncia, por sua vez, se caracteriza como a notificação à contraparte do desejo de resilir o contrato por um motivo que não se enquadre nas possibilidades de resolução ou rescisão. $\mathrm{O}$ efeito da denúncia é a resilição.

Em relação ao conceito de resilição, há clara divergência doutrinária. Pontes de Miranda a classifica como uma espécie de resolução, que se aplicaria aos contratos de prestação continuada. O Código Civil de 2002, no entanto, corrigindo impropriedade terminológica presente no Código Bevilaqua, regulou a resilição nos arts. 472 e 473, conforme a doutrina de Orlando Gomes e Caio Mário da Silva Pereira. A seguinte passagem do texto de Francisco Loureiro sobre a matéria é esclarecedora:

“Colocou o novo Código Civil ponto final à dúvida semântica que apenas embaralhava
conceitos e em nada contribuía para a compreensão da matéria: explicitou o que
entende por resilição e por resolução. Acolheu nosso Código Civil, nitidamente, a
sugestão de Orlando Gomes, para quem 'sob nome de resilição, usado pelos juristas
franceses, designa-se o modo de extinção dos contratos pela vontade de um ou dos dois
contratantes'. Resolução, por seu turno, é a extinção do contrato fundada no
inadimplemento, ou em razão da onerosidade excessiva. Os arts. 472 e 473 do Código
Civil disciplinam as duas hipóteses de resilição fundadas na vontade de ambas ou, ao
menos, de uma das partes do contrato. O distrato é a resilição bilateral (art. 472).
Regula em seguida a resilição unilateral, mediante denúncia de uma das partes (art.
473 ). Os arts. 474 e 475 do Código Civil disciplinam a resolução, fundada no
inadimplemento de um dos contratantes e seus dois mecanismos, a cláusula resolutiva
expressa e a cláusula resolutiva tácita. Os arts. 478 e 480, por sua vez, regulam as

19 PONTES DE MIRANDA. Tratado de Direito Privado. $4^{\text {a }}$ ed., São Paulo: Borsoi, 1959. t. 25, p. 281

20 AGUIAR JÚNIOR, Ruy Rosado de. Extinção dos contratos por incumprimento do devedor: resolução: de acordo com o novo Código civil. $2^{\mathrm{a}}$ ed. Rio de Janeiro: AIDE, 2003. p. 73 
hipóteses de resolução do contrato fundada em onerosidade excessiva, com a ressalva da possibilidade de preservação da avença, devolvendo-lhe o equilíbrio original perdido (art. 479 e 480 do CC). Em suma, a distinção fundamental entre a resilição e a resolução, por expressa opção do legislador, se encontra na causa de extinção do contrato, a primeira fundada na vontade e a segunda no inadimplemento ou na onerosidade excessiva." 21

Apesar do seu conceito de resilição não ter sido encampado pelo ordenamento, Pontes de Miranda contribuiu com a esclarecedora figura reproduzida abaixo, pela qual, literalmente, desenhou o que era difícil de explicar. A linha interna dos círculos corresponde ao momento de formação do contrato, enquanto a linha externa representa o seu cumprimento. Os sinais indicam o momento em que a relação contratual foi desfeita e os seus efeitos para as partes.
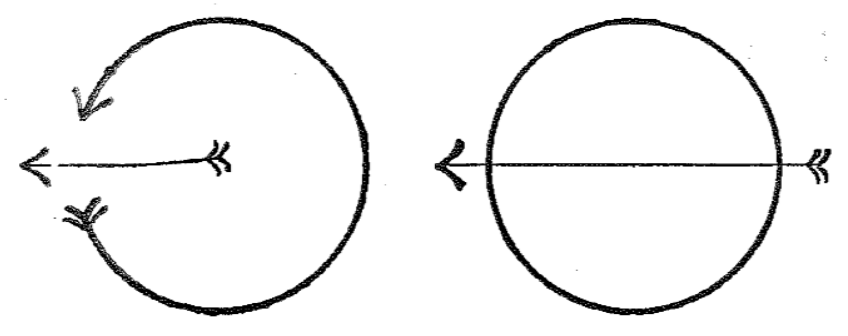

1. Revogação

2. Resusio
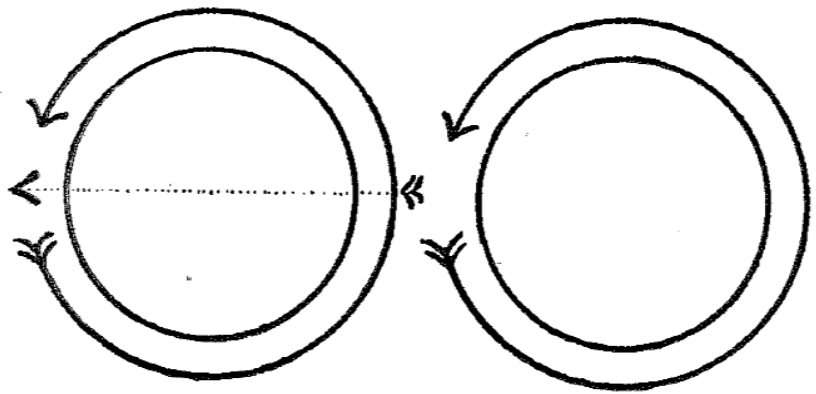

3. Resolução

4. Dustrato

${ }^{21}$ LOUREIRO, Francisco Eduardo. Extinção dos Contratos, in. Teoria Geral dos Contratos, São Paulo: Atlas, 2011, p. 610, coord. LOTUFO, Renan e NANNI, Giovanni Ettore 

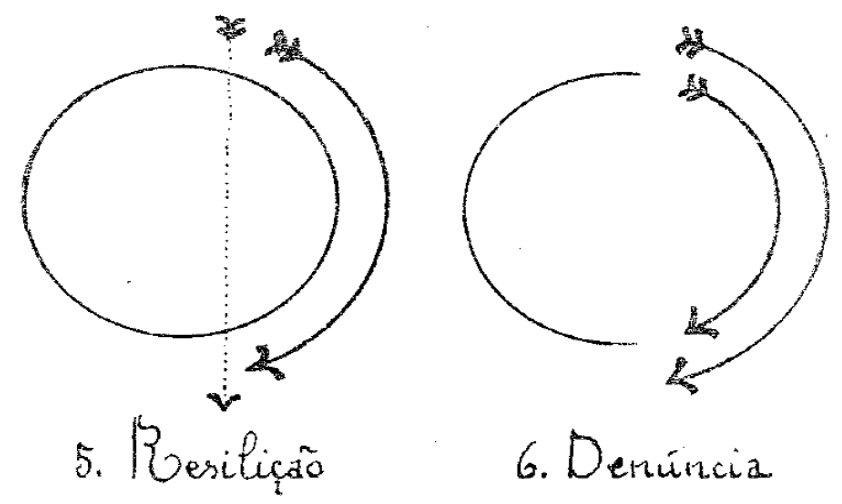

6. Denúncia
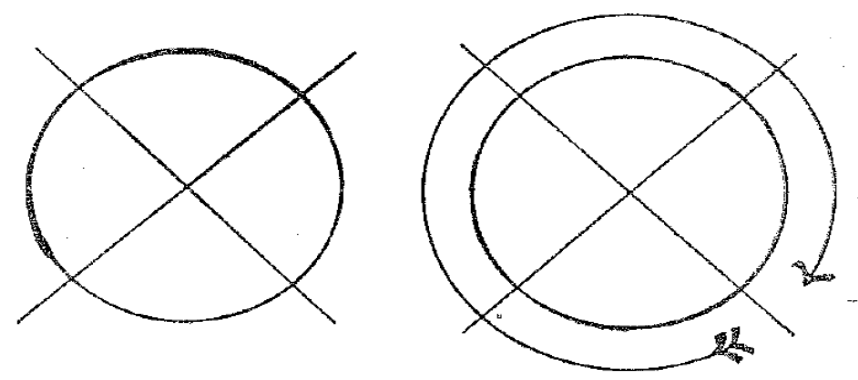
7. Decretaçáa de nulidade

8. Luculaçã

Do conceito de todos os mencionados institutos, extrai-se a definição de resolução com maior apuro. Nas palavras do ministro RUY ROSADO DE AGUIAR, a resolução por incumprimento do devedor pode ser definida como "resultado da manifestação de um direito formativo surgido com a superveniência do inadimplemento do devedor, no âmbito dos contratos bilaterais" 22 .

O direito potestativo - também chamado de formativo extintivo ${ }^{23}$ - à resolução do contrato nasce do inadimplemento qualificado do devedor ${ }^{24}$. Os limites ao exercício desse direito serão esmiuçados em capítulo próprio. Por ora, serão analisadas as espécies de resolução previstas no ordenamento brasileiro.

\subsubsection{Espécies de Resolução}

\footnotetext{
22 AGUIAR JÚNIOR, Ruy Rosado de. Extinção dos contratos por incumprimento do devedor: resolução: de acordo com o novo Código civil. $2^{\mathrm{a}}$ ed. Rio de Janeiro: AIDE, 2003. p. 74

23 AGUIAR JÚNIOR, Ruy Rosado de. Extinção dos contratos por incumprimento do devedor: resolução: de acordo com o novo Código civil. $2^{\mathrm{a}}$ ed. Rio de Janeiro: AIDE, 2003. p. 79

${ }^{24}$ PONTES DE MIRANDA. Tratado de Direito Privado. $4^{\mathrm{a}}$ ed., São Paulo: Borsoi, 1959. t. 25, p. 281
} 
A resolução pode se dar por meio de cláusula resolutiva expressa, em que as partes preveem a possibilidade de resolver o contrato em virtude de um fato específico. Nesses casos, a resolução pode ser dar por meio extrajudicial, conforme convencionado na cláusula resolutiva.

Nos demais casos, em que não houver regulação expressa das partes, o credor deverá ajuizar ação de resolução do contrato em face do devedor, alegando o descumprimento contratual. Esse sistema foi cunhado no Código Napoleão, havendo forte divergência com o sistema do BGB, conforme se discorrerá no próximo capítulo.

A resolução pode se dar, também, em relação à totalidade do contrato ou em relação a uma das suas prestações, pela impossibilidade superveniente do seu cumprimento por culpa do devedor.

Os efeitos da resolução em relação às partes também diferem conforme a natureza da prestação resolvida ${ }^{25}$. Se a relação contratual tratava de prestação de execução continuada, os efeitos se operam ex nunc, mantendo-se hígidas as prestações já cumpridas. A regra geral, no entanto, é que os efeitos da resolução se operem ex tunc, com o desfazimento de todos os atos jurídicos ocorridos após a celebração do contrato resolvido.

Analisadas as espécies de resolução no direito brasileiro, far-se-á, em seguida, breve incursão na gênese histórica do instituto, passando para o seu desenvolvimento até o conceito contemporâneo de resolução contratual.

\footnotetext{
${ }^{25}$ Gomes, Orlando. Contratos. 26 ${ }^{\mathrm{a}}$ ed. Rio de Janeiro: Forense, 2008, p. 210
} 


\section{Capítulo 2 - Origem Histórica da Resolução Contratual e Sistemas Contemporâneos}

\subsection{Direito Romano}

O Direito Romano não previa a hipótese de resolução contratual. Os credores em contratos de compra e venda eram protegidos por outros meios, como a ação reivindicatória. $\mathrm{O}$ regramento romano facilitava esse sistema, pois a propriedade do bem alienado só era transmitida com o recebimento do preço. Nos casos de pagamento diferido, era comum a previsão de uma cláusula denominada lex comissoria, que funcionava como condição resolutória em caso de não pagamento. Tal prática, no entanto, jamais foi institucionalizada pelos romanos $^{26}$.

\footnotetext{
26 AGUIAR JÚNIOR, Ruy Rosado de. Extinção dos contratos por incumprimento do devedor:
} resolução: de acordo com o novo Código civil. $2^{\mathrm{a}}$ ed. Rio de Janeiro: AIDE, 2003. p. 12/13 
Outra explicação para a ausência de regramento da resolução em Roma é a previsão do princípio de rescindenda venditione, segundo o qual ninguém podia se afastar de um contrato sem o consentimento dos contratantes ${ }^{27}$. Há, no entanto, um instituto que é apontado por alguns como a remota origem da resolução. Trata-se da conditio causa data, causa non secuta. Nas palavras de ARAKEN DE ASSIS:

"O gênio prático dos romanos cunhou um sistema diverso com vistas aos contratos inominados, ou seja, às convenções, lastreadas na concordância das vontades dos figurantes e cujo conteúdo não se reconhecia como tipo singular, em que somente a prestação de um dos contratantes obrigava a do outro, à semelhança, por exemplo, da permutatio. Em tal hipótese, a rebeldia do contratante não encontrava o paliativo da demanda de cumprimento, porque nenhuma ação se outorgava ao não inadimplente com este objetivo, gerando, assim, o contrapeso da conditio causa data, causa non secuta. Era um remédio contra o enriquecimento injustificado do contraente que não prestasse, frente ao inadimplente, de outro modo irremediavelmente indefeso. E, aqui, as modernas investigações do direito romano deparam o isolamento concreto da idéia subentendida na resolução. Na comventio re, tanto que inadimplida pelo accipiens a prestação, o dans, teria, a sua escolha, pretensão à repetição (conditio ob causam datorum) ou à prestação (actio praescriptis verbis). $\mathrm{O}$ exemplo apontaria a origem remota e tênue do instrumento resolutório." 28

Percebe-se, portanto, que, apesar da remota relação, não se pode extrair o conceito moderno de resolução do mencionado instituto. Não por acaso, JosÉ CARlos Moreira AlveS ${ }^{29}$ e EBERT CHAMOUN ${ }^{30}$ não mencionam a resolução nos seus manuais como instituto presente no direito romano em caso de inadimplemento de uma obrigação.

\section{$2.2 \quad$ Direito Feudal e Canônico}

\footnotetext{
${ }^{27}$ PONTES DE MIRANDA. Tratado de Direito Privado. $4^{\mathrm{a}}$ ed., São Paulo: Borsoi, 1959. t. 25, p. 281

28 ASSIS, Araken de Resolução do Contrato por Inadimplemento, $4^{\mathrm{a}}$ ed. São Paulo: Revista dos Tribunais, 2004, p. 44

${ }^{29}$ MOREIRA ALVES, José Carlos. Direito Romano, $13^{\mathrm{a}}$ ed., Rio de Janeiro: Forense, 2005

${ }^{30}$ CHAMOUN, Ebert. Instituições de Direito Romano, $5^{\text {a }}$ ed., Rio de Janeiro: Forense, 1968
} 
A origem mais provável do direito à resolução dos contratos está no direito feudal e no canônico ${ }^{31}$. No direito feudal existia a figura da comise, criada para sancionar os vassalos que abandonavam o feudo dos suseranos. Como a relação entre eles era contratual, nos casos em que a terra era abandonada e o vassalo se "desligava do senhor", o suserano podia declarar extinta a relação de vassalagem e retomar a terra. Tal instituto era utilizado para punir os vassalos pelo seu abandono, não tendo como objetivo restabelecer um equilíbrio contratual $^{32}$.

O instituto, no entanto, foi esquecido com o passar do tempo, cabendo, posteriormente, ao direito canônico estabelecer os princípios que nortearam a moderna regulação da resolução contratual. Nesse sentido, é atribuído ao jurista do século XII UGUCCIONE DA PISA a construção do instituto fundado na necessidade de equilíbrio entre as partes contratantes ${ }^{33}$. Nos seus manuscritos foi encontrado o adágio Fides non servanda est ei qui frangit idem (a quebra da palavra alheia libera da observância da própria) ${ }^{3435}$. Segundo seus estudos, o inadimplemento do devedor liberava o credor de cumprir suas obrigações contratuais, sendo tal máxima aplicável à generalidade dos contratos ${ }^{36}$.

Um dos alunos do jurista na renomada faculdade de Bolonha foi Lothario de Conti, posteriormente nomeado Papa Inocêncio III $^{37}$. Após assumir o papado em 1198, coube a ele difundir os ensinamentos do mestre, primeiramente por meio de carta enviada aos arcebispos e demais católicos da França em represália ao homicídio praticado por vassalo do Conde de Toulouse de um legado papal.

\footnotetext{
31 RIPERT, Georges et. PLANIOL, Marcel. Traité Pratique de Droit Civil Français, t. VI, Paris: Librairie Générale de Droit et de Jurisprudence, 1952, p. 570/571

32 AGUIAR JÚNIOR, Ruy Rosado de. Extinção dos contratos por incumprimento do devedor: resolução: de acordo com o novo Código civil. $2^{\mathrm{a}}$ ed. Rio de Janeiro: AIDE, 2003. p. 13

${ }^{33}$ PONTES DE MIRANDA. Tratado de Direito Privado. 4a ed., São Paulo: Borsoi, 1959. t. 25, p. 328

34 ASSIS, Araken de Resolução do Contrato por Inadimplemento, $4^{\mathrm{a}}$ ed. São Paulo: Revista dos Tribunais, 2004, p. 44

${ }^{35}$ Não se sabe ao certo a data do manuscrito, mas acredita-se que o princípio tenha sido cunhado anteriormente e a 1181, quando Lothario de Conti retornou a Roma após os seus estudos em Bolonha.

36 AGUIAR JÚNIOR, Ruy Rosado de. Extinção dos contratos por incumprimento do devedor: resolução: de acordo com o novo Código civil. $2^{\mathrm{a}}$ ed. Rio de Janeiro: AIDE, 2003. p. 14

${ }^{37}$ Informações do site: http://www.newadvent.org/cathen/07527a.htm - acesso em 14.05.15
} 
Na ocasião, o Papa fez referência ao mesmo princípio que aprendeu com UGUCCIONE para liberar os destinatários da carta do respeito aos bens e à pessoa do Conde ${ }^{38}$.

A utilização casuística, no entanto, é criticada por ter, assim como no direito feudal, caráter sancionatório, sem repercussão geral e abstrata ${ }^{39}$. No entanto, coube ao mesmo Papa suprir essa lacuna, ao emitir o decreto Quemadmodum, pelo qual liberou o marido de observar os deveres matrimoniais caso a mulher o traísse ${ }^{40}$. Gradativamente, o princípio se firmou no direito canônico, tendo sido mencionado em outros documentos emitidos por diversos Papas $^{41}$.

O direito canônico, no entanto, teve que enfrentar o fato de o juramento contratual ser feito, segundo seus princípios, perante o outro contratante e perante Deus. Como um juramento perante Deus não poderia ser desfeito, acatou-se a ideia de que tais obrigações foram assumidas "sob a condição implícita de que a outra parte cumpriria com a sua prestação" ${ }^{42}$. Na ausência da prestação da contraparte, o credor liberava-se também perante Deus.

Essa é a origem do regramento da cláusula resolutiva tácita, considerada pela vasta maioria da doutrina como presente em todos os contratos bilaterais e que serve de fundamento para o direito à resolução por incumprimento do contrato. PONTES DE MIRANDA lembra, no entanto, que UGUCCIONE DA PISA não fez referência ao conceito de "condição tácita" para o cumprimento ${ }^{43}$. Ambas as partes têm a obrigação de adimplir o contrato, ficando uma exonerada em caso

\footnotetext{
${ }^{38}$ PONTES DE MIRANDA. Tratado de Direito Privado. $4^{\mathrm{a}}$ ed., São Paulo: Borsoi, 1959. t. 25, p. 328

${ }^{39}$ PONTES DE MIRANDA. Tratado de Direito Privado. $4^{\mathrm{a}}$ ed., São Paulo: Borsoi, 1959. t. 25, p. 328

40 ASSIS, Araken de Resolução do Contrato por Inadimplemento, $4^{\mathrm{a}}$ ed. São Paulo: Revista dos Tribunais, 2004, p. 44

${ }^{41}$ ASSIS, Araken de Resolução do Contrato por Inadimplemento, $4^{\mathrm{a}}$ ed. São Paulo: Revista dos Tribunais, 2004, p. 44

42 AGUIAR JÚNIOR, Ruy Rosado de. Extinção dos contratos por incumprimento do devedor: resolução: de acordo com o novo Código civil. $2^{\mathrm{a}}$ ed. Rio de Janeiro: AIDE, 2003. p. 14

${ }^{43}$ PONTES DE MIRANDA. Tratado de Direito Privado. $4^{\mathrm{a}}$ ed., São Paulo: Borsoi, 1959. t. 25, p. $327 / 328$
} 
do descumprimento da outra, segundo a teoria do exceptio non adimplenti contractus, se estiver adimplente quando houver o inadimplemento alheio.

$\mathrm{O}$ direito à resolução, por outro lado, deriva do direito potestativo (formativo extintivo) de se desligar do contrato, não derivando de uma cláusula ou condição resolutiva tácita ${ }^{44}$, conforme entendimento firmado na Idade Média pelos juristas canônicos e encampado pelo Código Napoleão.

Os fundamentos que levaram ao regramento da resolução contratual por inadimplemento no Código Napoleão e no BGB, bem como a influência desses sistemas no regramento brasileiro serão objeto de estudo nos próximos capítulos.

Percebe-se, no entanto, que os princípios morais que embasaram os regramentos da Idade Moderna foram invocados primeiramente pelos canonistas da Idade Média, servindo de inspiração para os juristas que antecederam os Códigos Civis vigentes.

\subsection{O Sistema Francês}

$\mathrm{Na}$ falta de regras escritas, coube ao direito costumeiro francês, compilado pelos juristas que antecederam o Código Napoleão, criar a regra jurídica da possibilidade de resolução por inadimplemento do devedor ${ }^{45}$. Os trabalhos de Dumoulin e Domat, que, além de compilar as esparsas leis costumeiras francesas ${ }^{46}$ nos séculos XVI e XVII, criavam regras em conformidade com seu tempo, foram importantes inspirações para a posterior codificação civil francesa ${ }^{47}$.

\footnotetext{
${ }^{44}$ PONTES DE MIRANDA. Tratado de Direito Privado. $4^{a}$ ed., São Paulo: Borsoi, 1959. t. 25, p. $330 / 331$

${ }^{45}$ PONTES DE MIRANDA. Tratado de Direito Privado. $4^{a}$ ed., São Paulo: Borsoi, 1959. t. 25, p. 330

${ }^{46}$ Os costumes eram tão esparsos na França, tendo força de lei conforme o seu uso em cada vila na época que Voltaire chegou a afirmar que, à época, trocava-se de lei como trocava-se de cavalo.

${ }^{47}$ PONTES DE MIRANDA. Tratado de Direito Privado. $4^{\mathrm{a}}$ ed., São Paulo: Borsoi, 1959. t. 25, p. $336 / 338$
} 
No entanto, ao contrário do postulado canônico de fundamentar a resolução por inadimplemento na condição implícita presente no negócio jurídico de que a obrigação de cumprimento dependeria do adimplemento da contraparte, JEAN DOMAT, retomando o fundamento cunhado por UGUCCIONE DE PISA, afirmou ser a previsão legal da possibilidade de resolução por inadimplemento em caso de falta do devedor uma sanção legal prevista em regra jurídica cogente, que não derivaria, portanto, de uma condição, por ser inafastável pelas partes.

"A ratio legis está no ter-se de evitar que o inadimplente seja beneficiado por sua falta e que os outros credores executem o bem, enriquecendo-se injustificadamente. (...) Trata-se de mera sanção legal. A finalidade da lei foi pôr a sanção da resolução ou da resilição ainda onde não se pactuou expressa ou tacitamente. E isso viu, precisamente J.DomAT, em Les Lois Civiles, tão antes do Código Civil francês: 'l'inexécution des conventions de l apart d'un contractants peut donner lieu à la resolution, encore qu'il n'y ait pas de clause résolutoire, comme si le vendeur ne délibre pas la chose vendue'." 48

Posteriormente, René Pothier, um dos juristas que mais influenciou a redação do Código Civil Francês, reafirmou a inexistência de condição tácita para o adimplemento, sendo a resolução um direito do credor previsto no ordenamento por escolha do legislador para que o devedor inadimplente possa ser sancionado pela sua falta ${ }^{49}$.

Havia, no entanto, vozes dissonantes na doutrina francesa ${ }^{50}$, que prevaleceram em relação ao instituto da resolução na redação do Código Napoleão. Com efeito, o artigo que tratou do tema consagrou a tese de que a exigência do adimplemento dependeria, realmente, de uma condição tácita implícita em qualquer contrato bilateral, qual seja, a contraprestação da outra parte. O artigo 1184 do Código Napoleão foi formulado com a seguinte redação:

\footnotetext{
${ }^{48}$ PONTES DE MIRANDA. Tratado de Direito Privado. $4^{\text {a }}$ ed., São Paulo: Borsoi, 1959. t. 25, p. 338

${ }^{49}$ PONTES DE MIRANDA. Tratado de Direito Privado. $4^{a}$ ed., São Paulo: Borsoi, 1959. t. 25, p. 337

${ }^{50}$ PONTES DE MIRANDA. Tratado de Direito Privado. $4^{\mathrm{a}}$ ed., São Paulo: Borsoi, 1959. t. 25, p. 338
} 
"La condition résolutoire est toujours sous-entendue dans les contrats synallagmatiques, pour le cas où l'une des deux parties ne satisfera point à son engagement.

Dans ce cas, le contrat n'est point résolu de plein droit. La partie envers laquelle l'engagement n'a point été exécuté, a le choix ou de forcer l'autre à l'exécution de la convention lorsqu'elle est possible, ou d'en demander la résolution avec dommages et intérêts.

La résolution doit être demandée en justice, et il peut être accordé au défendeur un délai selon les circonstances." (grifou-se)

Inobstante as críticas feitas a essa escolha, tal dispositivo continua em vigor até hoje e influenciou diversos códigos promulgados nos séculos que se seguiram. O texto do referido artigo reflete, no entanto, outra importante escolha legislativa que possui, certamente, maior repercussão prática.

Trata-se da escolha pela necessidade de intervenção judicial para resolução do contrato em caso de ausência de cláusula resolutiva expressa, constante do terceiro parágrafo do artigo acima transcrito, tal como acontecia no direito canônico.

As consequências dessa escolha para a economia são enormes. Por um lado, confere-se ao juiz a árdua tarefa de analisar se estão presentes os requisitos in casu para a resolução contratual. Por outro, expõe-se o credor, lesado pelo inadimplemento, ao ônus de enfrentar longo processo judicial para satisfazer seu direito, conferindo vantagem ao devedor. Ganha-se em segurança jurídica ${ }^{51}$, perde-se em celeridade ${ }^{52}$. Nesse sentido, afirma RUY ROSADO DE AGUIAR o seguinte:

"Pela sua própria origem no Direito Canônico e como instrumento de equidade, a resolução judicial dos contratos bilaterais se presta exatamente para evitar que fique a

\footnotetext{
${ }^{51}$ Caio Mário da Silva Pereira aplaude o sistema francês, conforme se verifica da seguinte passagem: "Entre as duas orientações legislativas, ou os dois sistemas, parece-nos merecer aplausos o sistema entre nós vigente, que, se pode ser acusado de procrastianar o desfecho da resolução, na conformidade da lentidão do curso processual, oferece a utilidade de não sujeitar a estabilidade dos negócios aos caprichos ou ao precipitado comportamento de um dos contratantes, interessados na ruptura do vínculo, e de submeter as circunstâncias da inexecução ou da mora à apreciação imparcial e desapaixonada do Poder Judiciário." (Instituições de Direito Civil, Vol. III, $17^{\mathrm{a}}$ ed., Rio de Janeiro: Forense, 2012, pp. 138/139

${ }^{52}$ Sobre as vantagens e desvantagens de ambos os sistemas, ver: Gomes, Orlando. Contratos. $26^{\mathrm{a}}$ ed. Rio de Janeiro: Forense, 2008, p. 207/208
} 
extinção do contrato ao arbítrio de uma das partes. Apesar da morosidade que constrange as pessoas, o sistema judicial se constitui na garantira da conservação do justo equilíbrio entre os contratantes também no momento decisivo da extinção do contrato." ${ }^{, 53}$

Há, portanto, escolha do legislador em prestigiar um princípio jurídico em prol do outro. Não há como se condenar a escolha, apesar de ser passível de críticas, sobretudo considerando-se que o contrato deve ter como objetivo tornar mais eficazes as relações econômicas.

Posteriormente, na redação do Código Bevilaqua, esse foi o sistema acolhido. $\mathrm{O}$ histórico da norma no direito brasileiro será estudado mais à frente, contudo, pode-se perceber que o Código Napoleão teve influência decisiva na regulação da resolução de contratos por inadimplemento no direito nacional, sendo esse sistema importado por diversos Códigos ao redor do mundo.

\section{$2.4 \quad$ O Sistema Alemão}

Em contraposição ao sistema descrito acima, o BGB, ao tratar da resolução judicial em caso de ausência de cláusula resolutiva expressa, privilegiou a celeridade em detrimento da segurança jurídica. Pelo sistema alemão, havendo inadimplemento do devedor capaz de resolver o contrato sem cláusula resolutiva, tal instituto se opera por mera declaração do credor ao devedor ${ }^{54} 55$

Conforme mencionado acima, tal método privilegia a celeridade no desfazimento de uma relação jurídica indesejada pela parte prejudicada,

\footnotetext{
53 AGUIAR JÚNIOR, Ruy Rosado de. Extinção dos contratos por incumprimento do devedor: resolução: de acordo com o novo Código civil. $2^{\mathrm{a}}$ ed. Rio de Janeiro: AIDE, 2003. p. 14

${ }^{54}$ Gomes, Orlando. Contratos. $26^{\mathrm{a}}$ ed. Rio de Janeiro: Forense, 2008, p. 207

${ }_{55}$ Para uma visão esquemática das condições de resolução segundo o sistema alemão, ver: Schwab, Dieter et. Löhnig, Martin, Einführung in das Zivilrecht, Heidelberg: C.F. Müller, 2012, p. 397
} 
parecendo, portanto, mais justa, se desconsiderarmos os abusos que o sistema anterior certamente permite ${ }^{56}$.

Segundo o sistema alemão, caso o devedor entenda que o contrato não foi resolvido corretamente, deve recorrer ao Judiciário para restabelecer o contrato, ou pedir indenização. Inverte-se a ordem, o que pode causar injustiça em uma outra ponta da relação. Não há, portanto, sistema perfeito, devendo as eventuais injustiças serem compensadas pelo Judiciário da maneira mais justa, célere e eficiente.

Entendidos os dois modelos que inspiraram os Códigos Civis que foram consultados para o presente trabalho, passa-se a demonstrar a regulação da matéria no direito brasileiro, com os seus contornos inspirados no sistema francês.

\section{Capítulo 3 - A Resolução de Contratos no Direito Brasileiro}

\section{1 - Histórico do Instituto}

Vistos os dois principais sistemas existentes sobre resolução de contratos, cumpre analisar o instituto conforme regulado no direito brasileiro, desde a sua implementação, até os limites da sua atuação.

O marco legislatório sobre a resolução de contratos no Brasil é o Código Bevilaqua, que, no parágrafo único do art. 1.092, instituiu o direito à rescisão do contrato inadimplido pela contraparte, podendo, inclusive, reclamar perdas e danos. Eis a transcrição do artigo, para facilitar o exame:

"Art. 1.092. Nos contratos bilaterais, nenhum dos contraentes, antes de cumprida sua obrigação, pode exigir o implemento do outro. Se depois de concluído o contrato, sobrevier a uma das partes contratantes diminuição em seu patrimônio, capaz de comprometer ou tornar duvidosa a prestação pela qual se obrigou, pode a parte, a quem

56 AGUIAR JÚNIOR, Ruy Rosado de. Extinção dos contratos por incumprimento do devedor: resolução: de acordo com o novo Código civil. $2^{\mathrm{a}}$ ed. Rio de Janeiro: AIDE, 2003. p. 57 
incumbe fazer prestação em primeiro lugar, recusar-se a esta, até que a garantia bastante de satisfazê-la.

Parágrafo único. A parte lesada pelo inadimplemento pode requerer a rescisão do contrato com perdas e danos"'(grifou-se)

Inobstante a sua impropriedade terminológica ao usar o termo "rescisão" ao descrever um caso de resolução contratual, o dispositivo tem o mérito de garantir, de forma genérica e abstrata, ao lesado pelo inadimplemento da contraparte, a sua liberação das obrigações contratuais, acrescida de indenização pelas perdas e danos havidos com a falta do inadimplente.

Os manuais referentes ao Código Civil de 1916 mencionam esparsos dispositivos que tratam da matéria regulada no caput do art. 1.092 ${ }^{57}$. Quanto ao parágrafo único, há, somente no revogado Código Comercial, disposição equivalente, porém sem o mesmo grau de abrangência. Veja-se o referido dispositivo:

“Art. 202 - Quando o vendedor deixa de entregar a coisa vendida no tempo aprazado, o comprador tem opção, ou de rescindir o contrato, ou de demandar o seu cumprimento com os danos da mora; salvo os casos fortuitos ou de força maior."

Tais manuais também não indicam que tenha havido qualquer regulação do tema nas Ordenações Manuelinas, Afonsinas ou Filipinas, ou mesmo nas Consolidações e Esboços que antecederam o Código Civil de $1916^{58}$. Na falta de regulação expressa quanto à possibilidade de resolver o contrato em caso de inadimplemento, considera-se que tal hipótese era vista como um consectário lógico da falta do devedor, tal como o direito de restituição do que foi praticado até o momento da extinção do contrato, amplamente aceito na doutrina contemporânea conquanto não estivesse expressamente previsto no ordenamento.

\footnotetext{
${ }^{57}$ Bevilaqua, Clovis. Codigo Civil dos Estados Unidos do Brasil Commentado, $6^{\mathrm{a}}$ ed. Rio de Janeiro: Livraria Francisco Alves, 1943, p. 254

${ }^{58}$ ALVES, João Luiz. Código Civil da República dos Estados Unidos do Brasil, $3^{\mathrm{a} e d .}$ Rio de Janeiro: Borsoi, 1958, p. 187
} 
O Código Bevilaqua ${ }^{59}$, portanto, teve o mérito de suprir essa lacuna, sendo, desde a sua vigência, inafastável o direito de se liberar de obrigações contraídas em avença que foi descumprida pela outra parte. Durante o século $\mathrm{XX}$, muito se discutiu sobre os limites da utilização deste instituto, bem como procurou-se delimitar seus efeitos sobre as partes após o deferimento.

No entanto, o Código Civil de 2002 pouco acrescentou à regulação da matéria. Com efeito, incluiu-se a regra disposta no art. $474^{60}$, recepcionando o sistema francês, como era unânime na doutrina. $\mathrm{O}$ art. $475^{61}$, que corresponde ao art. 1.092 do Código Bevilaqua, acrescentou a hipótese de o credor preferir a exigência do cumprimento ao invés da resolução, se ainda houver o interesse na prestação. A medida é louvável, contudo, há discussões sobre o limite dessa possibilidade de escolha e os abusos que ela pode causar.

Passa-se a analisar, portanto, as duas questões que suscitam maiores polêmicas em relação ao instituto da resolução no ordenamento brasileiro: (i) os limites da sua atuação e (ii) as consequências para as partes após a sua efetivação.

\section{2 - Limitações à Resolução Contratual}

\footnotetext{
${ }^{5959}$ Interessante notar que, ao contrário do disposto no Código Napoleão, o Código Bevilaqua não fez referência à condição ou cláusula resolutória tácita. No entanto, a doutrina, filiando-se irrestritamente ao sistema francês e sem atentar para as diferenças em relação ao regramento brasileiro, fazia referência à presença de uma cláusula resolutiva implícita, deixando de atentar que a resolução funcionava, na verdade, como uma sanção legal a um comportamento independentemente da vontade das partes, configurando, portanto, sanção legal, e não cláusula ou condição. O Código Civil de 2002, encampando a lição da doutrina majoritária, incluiu a noção de cláusula resolutória tácita no art. 474. Veja-se, por todos, Orlando Gomes: Contratos. 26 a ed. Rio de Janeiro: Forense, 2008, p. 207 e SERPA LOPES, Miguel Maria de. Curso de Direito Civil, Vol. III, $6^{a}$ ed., Rio de Janeiro: Livraria Freitas Bastos, 1966, pp. 202/203. A crítica é de Pontes de Miranda. Tratado de Direito Privado. $4^{a}$ ed., São Paulo: Borsoi, 1959. t. 25 , p. 338

60 "Art. 474 - A cláusula resolutiva expressa opera de pleno direito; a tácita depende de interpelação judicial."

61 "Art. 475 - A parte lesada pelo inadimplemento pode pedir a resolução do contrato, se não preferir exigir-lhe o cumprimento, cabendo, em qualquer dos casos, indenização por perdas e danos."
} 
É pacífico na doutrina que nem todo inadimplemento dá direito à resolução contratual ${ }^{62}$. O primeiro requisito para que seja facultada ao credor a extinção do contrato por meio de resolução é que o inadimplemento da contraparte seja definitivo (classificado também como inadimplemento absoluto, essencial ou fundamental), ou qualificado de tal forma que retire o interesse na prestação devida ${ }^{63}$. A doutrina trata do tema sem grandes divergências, no entanto, recentemente desenvolveram-se diversos métodos para aperfeiçoar a aferição da possibilidade de resolução em caso de inadimplemento parcial.

Quanto à possibilidade de resolução em caso de incumprimento definitivo ou absoluto, tal tema não parece suscitar grandes questionamentos. $\mathrm{O}$ incumprimento definitivo, na preciosa definição de AGOSTINHO ALVIM, ocorre “quando a obrigação não foi cumprida, nem poderá sê-lo, como no caso de perecimento do objeto, por culpa do devedor" 64 . A regra, no caso de inadimplemento, é a reparação da falta com indenização pelas perdas e danos. A resolução contratual depende, nesse sentido, da comprovação de que o

\footnotetext{
${ }^{62}$ Mesmo os autores que insistem em se apegar à literalidade da lei, fazendo referência ao vocábulo "pode", previsto no art. 475 do Código Civil, em algum momento acabam admitindo que o nascimento do direito formativo extintivo de resolução não se opera em todos os casos de inadimplemento, devendo ser aplicado com temperança. Por todos, Eduardo Luiz Bussatta, Resolução dos Contratos e Teoria do Adimplemento Substancial, Rio de Janeiro, Saraiva: 2007, p. 89 e 113

${ }^{63}$ ASSIS, Araken de Resolução do Contrato por Inadimplemento, $4^{\mathrm{a}}$ ed. São Paulo: Revista dos Tribunais, 2004, p. 117; AGUIAR JÚNIOR, Ruy Rosado de. Extinção dos contratos por incumprimento do devedor: resolução: de acordo com o novo Código civil. $2^{\mathrm{a}}$ ed. Rio de Janeiro: AIDE, 2003. p. 93/94; ROPPO, Enzo. O Contrato, Coimbra: Livraria Almedina, 1978, p. 266; GONÇALVES, Carlos Roberto. Direito Civil Brasileiro, Vol. III, $2^{\mathrm{a}}$ ed. Rio de Janeiro: Saraiva, 2006, p. 162; SCHREIBER, Anderson. A triplíce transformação do adimplemento: Adimplemento substancial, inadimplemento antecipado $e$ outras figuras. In: Revista Trimestral de Direito Civil, vol. 32, Out-Dez. 2007, p. 24; RIZZARDO, Arnaldo. Contratos, $6^{\mathrm{a} e d .}$, Rio de Janeiro: Forense, 2006, p. 269; CASTRO NEVES, José Roberto de. Direito das Obrigações, $3^{\mathrm{a}}$ ed. Rio de Janeiro: GZ, 2012, p. 328; FERREIRA DA SILVA, Jorge Cesa. Inadimplemento das Obrigações. São Paulo: RT, 2006, p. 86. CARVALHO SANTOS, João Manuel de. Código Civil Brasileiro Interpretado. Vol. XV 13 ${ }^{\mathrm{a}}$ ed., São Paulo: Livraria Freitas Bastos, 1988. p. 247; Para uma análise mais aprofundada com base em um caso concreto, ver: GOMES, Orlando. Resolução de Venda por Defeito na Qualidade da Coisa, in. Questões de Direito Civil, $5^{\text {a }}$ d. Rio de Janeiro: Saraiva, 1988 , p. 72

${ }^{64}$ ALVIM, Agostinho, Da Inexecução das Obrigações e suas Consequências, $3^{\mathrm{a}}$ ed. Rio de Janeiro: Livraria Legislação Brasileira, 1965, p. 25
} 
inadimplemento leva à inutilidade da prestação devida para o credor. No caso do inadimplemento absoluto, essa inutilidade fica evidente.

No caso do inadimplemento parcial, no entanto, a apuração da possibilidade de resolução será mais difícil ${ }^{65}$. Deve-se perquirir se a falta do devedor é de tal monta que gera para o credor enorme frustração quanto à prestação contratada, de modo que o cumprimento defeituoso será, para ele, menos proveitoso que a extinção das obrigações contraídas com o retorno ao status anterior.

Nesse sentido, RUY ROSADO DE AGUIAR:

A impossibilidade parcial, decorrente de causa natural ou jurídica, é uma espécie de cumprimento imperfeito, imputável ou não ao devedor. Servirá de fundamento para o pedido resolutório se a falta ofender substancialmente o interesse do credor, tenha ou não havido culpa do devedor. A solução está nos arts. 235 e 236 do Código Civil. ${ }^{66}$

A aferição deve ser feita caso a caso, tendo em vista o objetivo de evitar o comprometimento daquilo que as partes previram obter ao contratarem, levando-se em conta os princípios da boa-fé objetiva e da função social do contrato.

Nesse sentido, a princípio, a simples impontualidade não gerará o direito formativo extintivo do contrato. Para que o credor pleiteie a resolução contratual, deverá ser capaz de provar que a pontualidade era critério essencial no contexto do contrato, sendo o retardamento na prestação grave o suficiente para fazer desaparecer o interesse no seu cumprimento. Para exemplificar essa questão, recorre-se ao gênio de Pontes de Miranda e Carvalho de Mendonça:

\footnotetext{
"Se a prestação fosse para ser feita em data fixa, ou dentro de certo prazo, mas inadmissível depois, não se poderia pensar em purgar da mora, nem em se pedir ao juiz a decisão sobre resolução ou resilição. Há, então, Fixgeschaft (negócio fixo), em que

${ }^{65}$ PLANIOL, Marcel, Traité Élémentaire de Droit Civil, t. XII, Paris: Librairie Générale de Droit \& de Jurisprudence, 1909, p. 445

${ }^{66}$ AGUIAR JÚNIOR, Ruy Rosado de. Extinção dos contratos por incumprimento do devedor: resolução: de acordo com o novo Código civil. $2^{\mathrm{a}}$ ed. Rio de Janeiro: AIDE, 2003. p. 93/94
} 
a resolução ou a resilição, e não só legal. Tal o que acontece se B tomou de aluguer a sacada para ver a passagem dos préstitos carnavalescos, ou a revista militar de 7 de setembro. Se a culpa é do devedor, há resolução ou resilição, se houve impossibilitação objetiva, com restituição do que recebeu e perdas e danos, ou o equivalente da prestação mais perdas e danos." 67

* $\quad * \quad *$

"Por exemplo: Pedro compra de João mil sacas de café para lhe serem entregues no dia tal, véspera da partida de um vapor para Hamburgo, onde o café ficou de ser entregue também em dia determinado, sendo esse o último vapor que poderia conduzir o café para lá chegar a tempo. Se, dias depois, João tenta entregar o café, pode Pedro enjeitar a prestação e exigir a satisfação das perdas e danos." 68

$\mathrm{O}$ fato de a prestação ter que ser inútil para que nasça o direito potestativo de resolução contratual está regulado no art. 395, parágrafo único, do Código Civil de $2002^{69}$, que reproduz o texto do parágrafo único do art. 956 do Código Bevilaqua. Nesse sentido, no caso de cumprimento pontual, porém defeituoso, também deverá ser empregado o critério da utilidade para que se determine a correção de um eventual pleito de resolução contratual ${ }^{70}$.

Tal hipótese é corretamente exemplificada por Clarissa Costa de Lima, conforme se verifica do seguinte trecho:

"Algumas vezes a mora pode vir a se constituir em incumprimento definitivo ou incumprimento absoluto, autorizando a resolução, quando a ele se agregar a perda do

\footnotetext{
${ }^{67}$ PONTES DE MIRANDA. Tratado de Direito Privado. $4^{\mathrm{a}}$ ed., São Paulo: Borsoi, 1959. t. 25, p. 340

${ }^{68}$ CARVALHO SANTOS, João Manuel de. Código Civil Brasileiro Interpretado. Vol. XII 13a ed., São Paulo: Livraria Freitas Bastos, 1988. p. 323

${ }^{69}$ Art. 395. Responde o devedor pelos prejuízos a que sua mora der causa, mais juros, atualização dos valores monetários segundo índices oficiais regularmente estabelecidos, e honorários de advogado. Parágrafo único. Se a prestação, devido à mora, se tornar inútil ao credor, este poderá enjeitá-la, e exigir a satisfação das perdas e danos.

${ }^{70}$ Art. 394 do Código Civil: Considera-se em mora o devedor que não efetuar o pagamento e o credor que não quiser recebê-lo no tempo, lugar e forma que a lei ou a convenção estabelecer. No BGB, a hipótese de mora serve apenas para o cumprimento impontual da prestação. Portanto, logo após a sua entrada em vigor, a doutrina alemã, através de Hermann Staub (1902), desenvolveu o conceito de violação positiva do contrato como possibilidade de resolução. Karl Larenz menciona o caso do reformador do telhado que, depois de cumprir o contratado, causa um incêndio no teto da casa, o que leva ao descumprimento de um dever de proteção. Derecho de Obligaciones, Madri: Revista de Derecho Privado, 1958, p. 362
} 
interesse do credor. Exemplo interessante é o da contratação de transporte de um valioso cavalo de São Paulo a Porto Alegre para a corrida do Grande Prêmio. O animal é entregue no local convencionado, na data e local estipulados no contrato; todavia, o caminhão no qual transportado não tinha cobertura, e o cavalo não fora alimentado. Chega no local convencionado, às vésperas do Grande Prêmio, totalmente exaurido, maltratado pelas adversas condições climáticas que sofrera no percurso, sem condições de participar da competição. Aqui, a prestação, considerada como um complexo de direitos e deveres, explícitos ou implícitos, não foi corretamente adimplida, embora tenha sido cumprida a obrigação principal de entrega no local e data convencionados. ${ }^{71}$

\title{
Os ordenamentos estrangeiros também condicionam a resolução pelo
}

atraso no cumprimento à perda de utilidade na prestação pelo credor, conforme demonstra o estudo realizado por ARAKEN DE ASSIS:

\begin{abstract}
"Não se mostra muito diverso o regime dominante do instituto em alguns sistemas jurídicos influentes. Um rápido bosquejo demonstra o estado do assunto e as inclinações da doutrina. Examinando o atraso no cumprimento, tendo em conta o tempo da prestação, sem dúvida fundamental na matéria, ensina Aurora González González admitir-se, no direito espanhol, a demanda resolutória somente quando o retardamento 'sea lo suficientemente grave que afecte al interés del acreedor'. Em sentido um pouco discrepante, no aspecto terminológico, Diez Picazo explica que o ataso 'no constituye mora en sentido técnico', porque a mora, específica infração ao crédito 'es siempre una causa que justifica la resolución'. Extensamente regulando a resolução, o direito italiano "na hipótese resolutiva - direito legal e dependente da demanda do interessado - que nos ocupa a atenção, concede o remédio se a inutilidade altera a mora, passandoa ao estado de inadimplemento absoluto." 72
\end{abstract}

O STJ, inclusive, utiliza o referido critério para balizar a aplicação do art.

475 do Código Civil, como se percebe do seguinte precedente:

SEGURO. INADIMPLEMENTO DA SEGURADA. FALTA DE PAGAMENTO DA ULTIMA PRESTAÇÃO. ADIMPLEMENTO SUBSTANCIAL. RESOLUCÃO. A COMPANHIA SEGURADORA NÃO PODE DAR POR EXTINTO O CONTRATO DE SEGURO, POR FALTA DE PAGAMENTO DA ULTIMA PRESTACÃO DO PREMIO, POR TRES RAZÕES: A) SEMPRE RECEBEU AS PRESTAÇÕES COM ATRASO, O QUE ESTAVA, ALIAS, PREVISTO NO CONTRATO, SENDO INADMISSIVEL QUE APENAS REJEITE A PRESTAÇÃO QUANDO OCORRA O SINISTRO; B) A SEGURADORA CUMPRIU SUBSTANCIALMENTE COM A SUA OBRIGAÇ̃̃O, NÃ̃O SENDO A SUA

\footnotetext{
${ }^{71}$ Reflexões sobre a resolução do contrato na nova teoria contratual, in. A Nova Crise do Contrato Estudos sobre a Nova Teoria Contratual - coord. Claudia Lima Marques - São Paulo: RT, 2007, p. 504

72 ASSIS, Araken de. Resolução do Contrato por Inadimplemento, $4^{\mathrm{a}}$ ed. São Paulo: Revista dos Tribunais, 2004, p. 115
} 
FALTA SUFICIENTE PARA EXTINGUIR O CONTRATO; C) A RESOLUÇÃO DO CONTRATO DEVE SER REQUERIDA EM JUIZO, QUANDO SERA POSSIVEL AVALIAR A IMPORTANCIA DO INADIMPLEMENTO, SUFICIENTE PARA A EXTINÇÃO DO NEGOCIO. RECURSO CONHECIDO E PROVIDO. ${ }^{73}$

$\mathrm{Na}$ falta de regulação legislativa sobre o tema, foram aprovados os enunciados 162 e 361 pelo Conselho da Justiça Federal, que trataram do tema confirmando os critérios utilizados pela jurisprudência. Veja-se a sua redação:

“162 - A inutilidade da prestação que autoriza a recusa da prestaç’ão por parte do credor deverá ser aferida objetivamente, consoante o princípio da boa-fé e a manutenção do sinalagma, e não de acordo com o mero interesse subjetivo do credor".

“361 - O adimplemento substancial ${ }^{74}$ decorre dos princípios gerais contratuais, de modo a fazer preponderar a função social do contrato e o princípio da boa-fé objetiva, balizando a aplicação do art. 475 ".

Discute-se, igualmente, se o incumprimento de uma obrigação acessória seria capaz de gerar a resolução contratual. A doutrina é pacífica em afirmar a possibilidade, mais uma vez recorrendo ao critério da utilidade como norteador para a definição da possibilidade de resolução. Nesse sentido, as lições de RUY ROSADO DE AGUIAR:

"Para a resolução, porém, não basta o simples incumprimento: é preciso trazer à baila o princípio consagrado no parágrafo único do art. 395: 'Se a prestação, devido à mora, se tornar inútil ao credor, este poderá enjeitá-la, e exigir a satisfação das perdas e danos'. Quer dizer, o incumprimento, para ser definitivo e causa de resolução, deve ser

\footnotetext{
${ }^{73}$ REsp 76.362/MT, Rel. Ministro Ruy Rosado de AguiaR, 4 $4^{a}$ Turma, j. em 11.12.95, DJ 01.04.96 grifou-se

${ }^{74}$ Sobre o tema, na doutrina americana: PERILLO, Joseph, Calamari and Perillo on Contracts, $5^{\text {a }}$ ed., St. Paul: Thomson/West, pp. 433/435 e FULLER, Lon L. et. EISENBERG, Melvin Aron, Basic Contract Law, St. Paul: West Group, 2001, pp. 902/910
} 
qualificado por essa perda de interesse do credor, decorrente da inutilidade da prestação." 75

Em relação à aferição da utilidade, o critério mencionado com maior frequência pela doutrina é o da análise das consequências do inadimplemento para a economia do contrato. Se a falta causada levar a uma desproporção de tal monta que a indenização não possa suprir, o cumprimento torna-se inócuo para o devedor, sendo-lhe preferível a resolução.

São de grande valia, também, os critérios utilizados pelos princípios do UNIDROIT, que caracterizam a possibilidade de resolução contratual somente em caso de inexecução essencial. Os princípios procuram estabelecer critérios para a aferição desse grau de inexecução, conforme exposto por Lauro Gama e Souza Jr.

\begin{abstract}
"No sistema dos Princípios, a resolução só tem lugar nos casos de inexecução essencial. Esta é disciplinada pelo artigo 7.3.1 (2), que, em vez de defini-la, indica os critérios a serem levados em conta na determinação da essencialidade da inexecução, respeitadas as características de cada caso concreto. Assim, a inexecução será essencial quando: a) privar substancialmente o credor daquilo que legitimamente esperava do contrato, salvo se o devedor não previu ou não podia razoavelmente prever tal resultado; b) o cumprimento estrito da obrigação for da essência do contrato; c) a inexecução for intencional ou temerária; d) a inexecução criar no credor a convicção de que ele não poderá contar com o cumprimento futuro pela outra parte; e e) o devedor vir a sofrer, em caso de resolução, um prejuízo excessivo resultante da preparação ou da execução do contrato. Não é necessário que tais critérios sejam cumulativos, em sua totalidade, mas é indispensável que concorram, em certa medida, para determinar à luz do caso concreto, se houve, ou não, inexecução essencial do contrato."76
\end{abstract}

Por todos esses critérios, verifica-se que há uma tentativa da doutrina de manter os contratos eficazes, por ser a sua resolução extremamente penosa para a economia, como anteriormente exposto.

\footnotetext{
75 AGUIAR JÚNIOR, Ruy Rosado de. Extinção dos contratos por incumprimento do devedor: resolução: de acordo com o novo Código civil. $2^{\mathrm{a}}$ ed. Rio de Janeiro: AIDE, 2003. p. 115

${ }^{76}$ GAMA e SOUZA JR., Contratos Internacionais à luz dos Princípios do UNIDROIT 2004 - Soft Law, Arbitragem e Jurisdição. Rio de Janeiro: Renovar, 2006, p. 376/377
} 
Nesse sentido, o princípio da conservação dos contratos ${ }^{77}$ também atua como um limitador para a aplicação da resolução contratual, considerando os seus efeitos para as partes e para a sociedade como um todo ${ }^{78}$. Quando houver dúvida sobre o inadimplemento contratual de uma parte, interpretar-se-á o contrato a seu favor, evitando que o acordo seja desfeito por uma interpretação que facilite o seu desfazimento.

Assim como ocorre na conversão do negócio jurídico quando o efeito desejado era diferente daquele contratado, ou tendo havido simulação ${ }^{79}$, um descumprimento pouco gravoso que não desvirtue o objetivo principal do contrato não pode atingir o todo, sob pena de tornar sem efeito um conjunto de obrigações assumidas pelas partes apenas por uma pequena falha do devedor.

O princípio da conservação do negócio jurídico atua, ainda, a permitir a resolução parcial do contrato, quando uma parte do seu programa estiver comprometido, mantendo-se hígida a parcela restante ${ }^{80}$.

\footnotetext{
${ }^{77}$ Sobre o referido princípio na interpretação do negócio jurídico, ver: MARINO, FRANCISCO: A Interpretação do Negócio Jurídico. São Paulo: Saraiva, 2011, pp. 307/342

${ }^{78}$ Nesse sentido: "CONSIGNAÇÃO EM PAGAMENTO E RESOLUÇÃO CONTRATUAL COM REINTEGRAÇÃO DE POSSE E PEDIDO DE INDENIZAÇÃO. Cessão de direitos de contrato de compromisso de compra e venda. Cessionária que deixou de pagar tempestivamente seis parcelas da obrigação contraída e pretende depositar o valor em juízo para quita-las. Cedentes que se recusam a receber o valor das prestações e pretendem resolver o contrato, obter a reintegração na posse do imóvel e ser indenizados pelo período de ocupação indevida. Devedora que depositou em juízo todo o valor devido, parte já levantada pelos credores. Impossibilidade de extinção do negócio, à luz da teoria da conservacão dos contratos. Precedentes deste E. Tribunal. Sentença mantida. Recurso desprovido." (TJ/SP - AP 0039044-20.2010.8.26.0602, Rel. Des. Milton CARVAlHO, 4 ${ }^{\text {a }}$ Câmara de Direito Privado, j. em 27.03.14, DJ 03.04.14 - grifou-se)

${ }^{79}$ Sobre o tema, discorre Humberto Theodoro Júnior: "Nas simulacões parciais, a nulidade incidirá normalmente sobre a parte do negócio em que se deu a falsidade, salvo se for impossível manter o negócio com a amputação da porção nula. A regra, porém, é, podendo separar-se a porção viciada, a nulidade da parte não afetará o todo. Utile per inutile non vitiatur. Se, pois, a simulação está no preço ou na data, a nulidade afetará apenas esses elementos, e o negócio prevalecerá com o preço e a data verdadeiros, como se não existissem os dados simulados, para todos os efeitos. (...) Nos instrumentos particulares a aposição de data não verdadeira (antedata ou pós-data) é forma de simulação parcial do negócio. Trata-se de simulação relativa, porque debaixo do negócio aparente existe um verdadeiro que, entretanto, se consumou em momento diverso do mencionado pelas partes. (...)" A nulidade da simulação afeta apenas a data, fazendo com que o negócio venha a ser situado no tempo verdadeiro de sua celebração." (Comentários ao novo Código Civil, volume 3, t. 1: livro III - dos fatos jurídicos: do negócio jurídico. - Rio de Janeiro: Forense, 2003, p. 484 - destacou-se).

80 ASSIS, Araken de. Resolução do Contrato por Inadimplemento, $4^{a}$ ed. São Paulo: Revista dos Tribunais, 2004, p. 162/163; AZEVEDO, Antonio Junqueira de. Natureza Jurídica do contrato de consórcio. Classificação dos atos jurídicos quanto ao número de partes e quanto aos efeitos. Os
} 
A doutrina mais recente destaca, também, a necessidade de o juiz analisar o pedido de resolução sob a ótica dos princípios da função social e econômica dos contratos ${ }^{81}$ e da boa-fé objetiva. Afirma-se que o juiz deve se preocupar com as consequências da ruptura do contrato para a sociedade como um todo, considerando a sua função econômica para a atividade que tutela ${ }^{8283}$.

contratos relacionais. Alteração das circunstâncias e onerosidade excessiva. Resolução parcial do contrato. Função social do contrato. In. Revista Trimestral de Direito Civil, vol. 21, Jan-Mar. 2005, p. 264.

${ }^{81}$ Sobre o referido princípio e as suas implicações nos contratos, verificar, ainda: TEPEDINO, Gustavo: Notas sobre a função social dos contratos. In. O Direito \& o Tempo, Org. TEPEDINO, Gustavo e FACHIN, Luiz Edson. Rio de Janeiro: Renovar, 2008, pp. 395/405; KONDER, Carlos Nelson e RENTERÍA, Pablo. A funcionalização das relações obrigacionais: interesse do credor e patrimonialidade da prestação. In. Diálogos sobre Direito Civil, Vol. II, TEPEDINO, Gustavo e FACHIN, Luiz Edson. Rio de Janeiro: Renovar, 2008, pp. 265/297; TIMM, Luciano Benetti. Direito, Economia e a Função Social do Contrato. In. Função Social do Direito. Coord. TIMM, Luciano Benetti e MACHADO, Rafael Bicca. São Paulo: Quartier Latin, 2009, pp. 173/193; FONSECA, Rodrigo Garcia da. A Função Social do Contrato e o Alcance do Artigo 421 do Código Civil. Rio de Janeiro: Renovar, 2007; GOMES, Rogério Zuel. Teoria Contratual Contemporânea, Rio de Janeiro: Forense, 2004; THEODORO JÚNIOR, Humberto. O Contrato e sua Função Social. $2^{\mathrm{a}}$ ed. Rio de Janeiro: Forense, 2004 e NEGREIROS, Teresa. Teoria do Contrato - Novos Paradigmas, Rio de Janeiro: Renovar, 2002, pp. $205 / 267$

${ }^{82}$ Nesse sentido, AGUIAR JÚNIOR, Ruy Rosado de. Extinção dos contratos por incumprimento do devedor: resolução: de acordo com o novo Código civil. $2^{\mathrm{a}}$ ed. Rio de Janeiro: AIDE, 2003. pp. 235. Na doutrina internacional, GENICON, Thomas. La Résolution Du Contrato Pour Inexécution, Paris: L.G.D.J, 2007, pp. 365/368; Clarissa Costa de Lima chega a cogitar a hipótese de o juiz negar a resolução mesmo com a presença de cláusula expressa, em situações excepcionais, devendo-se privilegiar a ética em detrimento do abuso. Reflexões sobre a resolução do contrato na nova teoria contratual, in. A Nova Crise do Contrato - Estudos sobre a Nova Teoria Contratual - coord. Claudia Lima Marques - São Paulo: RT, 2007, p. 515. Ainda, sobre a função econômica e social dos contratos, ver: MECHELANY VELOSO, Silvia. Análise Econômica e Função Social dos Contratos - art. 421 do Código Civil. in. Revista de Direito Privado, vol. 54, Abril-Junho 2013, RT.

${ }^{83}$ Por outro lado, em caso de perda da função social do contrato, o mesmo poderá ser extinto, pois não trará mais benefícios econômicos para as partes e a sociedade como um todo. Haverá uma "desnaturação" do seu fim. Sobre o tema, Antonio Junqueira de Azevedo faz referência e exemplos esclarecedores: "O fim que não mais pode ser atingido faz com que o contrato perca sua função social, devendo torna-lo juridicamente ineficaz. Entre os casos de frustração do fim do contrato que agora encontram legalmente um 'lugar cômodo' sob a exigência da função social, estão os 'coronation cases' de Windscheid, quando, na Inglaterra, cidadãos alugaram sacadas e terraços, para assistir a passagem do cortejo de Eduardo VII, se viram frustrados com o cancelamento do percurso de carruagens (mas as janelas e sacadas permaneceram à disposição); ou também o caso de Larenz, do artesão, que, na Alemanha, insistia em fazer a porta da igreja, já demolida por bombardeio aliado, porque o contrato havia sido assinado; e, assim, inúmeras outras situações em que, sem haver impossibilidade da prestação, o verdadeiro fim do contrato, conhecido das duas partes, já não pode ser atingido. Em todas essas hipóteses, o contrato, tornado inútil, deve ser resolvido por falta de função social. A impossibilidade da obtenção do fim último visado pelo contrato constitui, a nosso ver, juntamente com a ofensa a interesses coletivos (meio-ambiente, concorrência, etc.) e a lesão à dignidade da pessoa humana, os três casos em que a função social do contrato deve levar à ineficácia superveniente. A perda de função social pode ocorre, como é natural, com cláusula de contrato.” AZEVEDO, Antonio Junqueira de. Natureza Jurídica do contrato de consórcio. Classificação dos atos jurídicos quanto ao número de partes e quanto aos efeitos. Os contratos relacionais. Alteração das circunstâncias e onerosidade 
Portanto, considerando os critérios balizadores determinados pela doutrina nacional e internacional, bem como pela jurisprudência, é impositivo analisar pedidos de resolução contratual restritivamente, buscando-se a manutenção dos contratos sempre que for possível.

\subsection{Efeitos da Resolução Contratual}

A resolução extingue as obrigações contratadas, devendo as partes retornar ao estado anterior à formação do contrato. Portanto, se por um lado o inadimplemento qualificado gera o direito potestativo à resolução contratual, a confirmação da resolução gera o direito subjetivo à restituição do que foi despendido no curso da relação contratual pelas partes.

Tal direito, apesar de não estar expresso na legislação, é corolário lógico da extinção do contrato, sendo reconhecido pela doutrina de forma unânime ${ }^{84}$. A jurisprudência o aplica de forma igualmente pacífica, conforme se extrai dos seguintes precedentes do STJ:

RECURSO ESPECIAL. DIREITO CIVIL. RESOLUÇÃO DE CONTRATO. PROMESSA DE COMPRA E VENDA DE IMÓVEL. DETERMINAÇÃO DE RESTITUIÇÃO, PELO PROMITENTE VENDEDOR, DAS PARCELAS DO PREÇO PAGAS PELOS PROMITENTES COMPRADORES. DESNECESSIDADE DE PEDIDO EXPRESSO DOS RÉUS. CONCRETIZAÇÃO DA EFICÁCIA RESTITUTÓRIA DA RESOLUÇÃO. INOCORRÊNCIA DE DECISÃO 'EXTRA PETIA'. 1. Decretada a resolução do contrato de promessa de compra e venda, deve 0 juiz, ainda que não tenha sido expressamente provocado pela parte interessada, determinar a restituicão, pelo promitente vendedor, das parcelas do preco pagas pelos promitentes compradores. 2. Concretização da eficácia

excessiva. Resolução parcial do contrato. Função social do contrato. In. Revista Trimestral de Direito Civil, vol. 21, Jan-Mar. 2005, p. 264. Sobre a Frustração do Fim do Contrato ver, ainda, COGO, Rodrigo

Barreto. A Frustração do Fim do Contrato - O impacto dos fatos supervenientes sobre o programa contratual. Rio de Janeiro: Renovar, 2012. Sobre o desaparecimento da causa do contrato, ver COMPARATO, Fabio Konder. Notas sobre a resolução de contratos. In. Direito Empresarial, Rio de Janeiro: Saraiva, 1990, p. 380 e GOMES, Orlando. Resolução de Venda por Inutilidade da Coisa Vendida, in. Questões de Direito Civil, 5ad. Rio de Janeiro: Saraiva, 1988, p. 72

84 AGUIAR JÚNIOR, Ruy Rosado de. Extinção dos contratos por incumprimento do devedor: resolução: de acordo com o novo Código civil. $2^{\mathrm{a}}$ ed. Rio de Janeiro: AIDE, 2003. pp. 259/262; ASSIS, Araken de. Resolução do Contrato por Inadimplemento, $4^{\mathrm{a}}$ ed. São Paulo: Revista dos Tribunais, 2004, pp. $156 / 160$ 
restitutória da resolução, aplicável em benefício das duas partes do contrato, como consequência natural da desconstituicãa do vínculo contratual. 3 . Inocorrência de decisão "extra petita". 4. Reafirmação da jurisprudência da Terceira e da Quarta Turma deste STJ acerca do tema. 5. RECURSO ESPECIAL NÃO PROVIDO. ${ }^{85}$

DIREITO CIVIL. COMPROMISSO DE COMPRA E VENDA. ARRAS. RESOLUÇÃO. EFEITOS. CORREÇÃO. RECURSO PROVIDO. I - OPERADA $\underline{\mathbf{A}}$ RESOLUÇ̃̃O CONTRATUAL POR CULPA DE AMBOS OS CONTRAENTES, IMPOE-SE O RETORNO AO STATUS QUO ANTE, INCLUSIVE COM DEVOLUCÃO DAS ARRAS. II - A RESTITUIČ̃̃O INTEGRAL PRESSUPOE $O$ REEMBOLSO DAS QUANTIAS PAGAS, INCIDINDO A CORREĈ̃̃ O DA MOEDA A PARTIR DO EFETIVO DESEMBOLSO. III - A IMPOSIÇÃO DE CORREÇÃO MONETARIA INDEPENDE DE PEDIDO EXPRESSO IV - ENQUANTO A RESCISÃO CONTRATUAL SE OPERA POR VICIO DE FORMA OU CONSENTIMENTO, A RESOLUÇÃO TEM POR FUNDAMENTO O INADIMPLEMENTO CONTRATUAL, DE UMA OU DE AMBAS AS PARTES. ${ }^{86}$

Por essa persistência no dever de restituição, KARL LARENZ afirma que o inadimplemento é uma fase da relação obrigacional, que, portanto, não está totalmente extinta ${ }^{87}$. Instaura-se, nesse momento, o que a doutrina chama de relação de liquidação entre as partes, para que seja possível restituir aquilo que foi desembolsado com o contrato resolvido.

Muitas vezes, no entanto, não é possível a restituição de um bem, pois ele foi transferido para um terceiro, ou o bem transferido era perecível, como no caso de alimentos. Nesses casos, a solução é a conversão em perdas e danos. Dessa maneira, prestigia-se o terceiro de boa-fé, que, por outro lado, não merecerá tutela no caso de cláusula resolutória expressa apontada no registro geral de imóveis ${ }^{88}$.

\footnotetext{
${ }^{85}$ REsp 1286144/MG, Rel. Ministro PAULO DE TARSO SANSEVERINO, TERCEIRA TURMA, julgado em 07/03/2013, DJe 01/04/2013 - grifou-se

${ }^{86}$ REsp 22.830/RJ, Rel. Ministro SÁLVIO DE FIGUEIREDO TEIXEIRA, QUARTA TURMA, julgado em 15/06/1992, DJ 17/08/1992 - grifou-se

${ }^{87}$ LARENZ, Karl. Derecho de Obligaciones, , Madri: Revista de Derecho Privado - Editorial, 1958, p. 394

${ }^{88}$ AGUIAR JÚNIOR, Ruy Rosado de. Extinção dos contratos por incumprimento do devedor: resolução: de acordo com o novo Código civil. $2^{\mathrm{a}}$ ed. Rio de Janeiro: AIDE, 2003. pp. 263
} 
Interessante disposição figura no direito alemão, sobre a consequência do desrespeito ao direito de restituição. Preceitua o $\S 354$ do BGB $^{89}$ que o descumprimento desse preceito devolve a eficácia ao contrato extinto. Não há dispositivo semelhante no direito brasileiro que preveja tal situação.

Outra questão interessante em relação à resolução é o alcance da indenização por perdas e danos que será pleiteada pela parte adimplente. No sistema brasileiro, ao contrário do que vige na maioria dos ordenamentos estrangeiros, admite-se a tutela não somente do interesse negativo, que corresponde aos danos emergentes pela não concretização do negócio, como também do interesse positivo, que corresponde aos lucros cessantes pela resolução do contrato ${ }^{90}$.

$\mathrm{O}$ art. 475 do Código Civil faz referência às perdas e danos, que abrangem, nos termos do art. 402 do mesmo diploma legal, tanto os danos emergentes quanto os lucros cessantes. Por essa opção legislativa, não há como seguir o modelo de ressarcimento apenas pelos danos emergentes. Com efeito, não convence a justificativa para o afastamento da indenização por lucros cessantes defendida por Mario Júlio de Almeida Costa ${ }^{91}$, pois a extinção do contrato, conquanto tenha sido requerida pelo credor, é imputável à conduta do devedor.

Ora, se não houvesse inadimplemento, o direito potestativo à resolução não surgiria, e o contrato teria o seu regular prosseguimento.

\footnotetext{
89 "Verwirkungsklausel: Ist ein Vertrag mit dem Vorbehalt geschlossen, dass der Schuldner seiner Rechte aus dem Vertrag verlustig sein soll, wenn er seine Verbindlichkeit nicht erfüllt, so ist der Gläubiger bei dem Eintritt dieses Falles zum Rücktritt von dem Vertrag berechtigt."

90 AGUIAR JÚNIOR, Ruy Rosado de. Extinção dos contratos por incumprimento do devedor: resolução: de acordo com o novo Código civil. $2^{\mathrm{a}}$ ed. Rio de Janeiro: AIDE, 2003. pp. 266/271

91 "Optando o lesado pela resolução do contrato, seria em substância contraditório que, ao mesmo tempo, pedisse a indenização pelo seu não-cumprimento. O que decorre da lógica e coerência dessa opção é colocar o prejudicado na situação em que se encontraria se o contrato não houvesse sido celebrado." ALMEIDA COSTA, Mário Júlio de. Direito das Obrigações, $8^{a}$ ed. Coimbra: Almedina, 2000, p. 966. No mesmo sentido: VARELA, Antunes. Das Obrigações em Geral. 2ª ed. Coimbra: Almedina, 1974, pp. $103 / 108$
} 
Aplicam-se à restituição as regras de devolução de melhoramentos relativos à acessão e colheita dos frutos percebidos ${ }^{92}$ e pendentes para o possuidor de boa-fé, bem como a necessidade de indenização em relação às benfeitorias necessárias e úteis, além das voluptuárias que tenham sido autorizadas ${ }^{93}$. Em suma, deverão ser adotadas todas as medidas para que as partes voltem ao estado anterior, em respeito ao princípio da equidade e para evitar o enriquecimento sem causa.

Essas são, em linhas gerais, as principais características do direito potestativo à resolução por inadimplemento do devedor conforme o ordenamento brasileiro.

No entanto, consoante adiantado na introdução dessa monografia, em outubro de 2014 foi incorporada ao ordenamento pátrio a Convenção de Comércio Internacional de Mercadorias (CISG), que possui regramento específico em relação à resolução de contratos internacionais de compra e venda de mercadorias. O parâmetro diferenciado da CISG para a resolução de contratos será analisado a seguir, após uma breve digressão sobre os princípios gerais da convenção.

\footnotetext{
${ }^{92}$ ENNECERUS, Ludwig, KIPP, Theodor et. WOLFF, Martin. Derecho de Obligaciones, t. II, Vol. $1^{\circ}$, Barcelona: Bosch, 1954, p. 251

${ }_{93}$ ASSIS, Araken de. Resolução do Contrato por Inadimplemento, $4^{\mathrm{a}}$ ed. São Paulo: Revista dos Tribunais, 2004, pp. 169/170
} 


\section{Capítulo 4 - Resolução de Contratos na Convenção de Comércio Internacional de Mercadorias - CISG}

\section{1 - Histórico da Convenção}

As rotas de comércio internacional tiveram seu início na Idade Antiga, mesmo antes das Grandes Navegações. No entanto, foi na Idade Média, com o desenvolvimento do comércio através da abertura de rotas marítimas antes não exploradas, que os mercadores buscaram estabelecer normas comuns para regular as transações que envolviam negócios internacionais. $\mathrm{O}$ conjunto de normas desenvolvido por esses agentes do mercado internacional ficou conhecido como lex mercatoria ${ }^{94}$.

94 BAPTISTA, Luiz Olavo, Lex Mercatoria, in. Arbitragem Doméstica e Internacional, Coord. FERRAZ, Rafaella e MUNIZ, Joaquim de Paiva, Rio de Janeiro: Forense, 2008, pp. 279/289 e BASSO, Larissa de Santis, Contratos Transnacionais e o fundamento da arbitragem comercial internacional: um enfoque didático, in. Arbitragem nacional e internacional - Os novos debates e a visão dos jovens arbitralistas, Coord. MOTTA PINTO, Anna Luiza Baccarat e SKITNEVSKY, Karin Hlavnicka, Rio de Janeiro: Elsevier, 2012, pp. 284/289 
O conjunto de regras que deu origem à lex mercatoria foi desenvolvido pelas corporações de ofício (também conhecidas como guildas) que representavam certos setores negociais para regular as suas relações na Idade Média, sobretudo nas feiras medievais que deram origem às cidades. $\mathrm{O}$ desenvolvimento desse conceito deu origem ao conjunto de regras aceito hoje no contexto internacional para orientar o comércio entre nacionais de diferentes países.

Tais regras, no entanto, eram esparsas e careciam de uma codificação que obrigasse comerciantes ao redor do mundo de maneira definitiva. Apenas após a unificação das últimas nações europeias e o fim da primeira guerra mundial, quando as nações vencedoras vislumbraram a necessidade de formar uma coalizão para garantir a paz, iniciou-se a busca por uma codificação comum.

Nesse contexto, o jurista alemão ERNST RABEL, considerado o pai do direito comparado moderno, foi protagonista na formação do Instituto Internacional para a Unificação do Direito Privado (UNIDROIT), em 1926, órgão auxiliar da Liga das Nações. Na condição de presidente do UNIDROIT, em 1928, RABEL propôs, pela primeira vez, uma codificação comum para regular os contratos transnacionais ${ }^{95}$.

No entanto, com a dissolução da Liga das Nações em 1939 e a Segunda Guerra Mundial, os planos para a codificação comum foram adiados ${ }^{96}$, sendo possível a aprovação da uma convenção internacional apenas em 1964. Naquela ocasião, foram aprovadas a Convenção para Lei Uniforme relativa à Compra e Venda Internacional (ULIS) e a Convenção para Lei Uniforme sobre a Formação dos Contratos de Compra e Venda Internacional (ULF). No entanto, tais convenções não tiveram grande adesão, o que frustrou a sua finalidade.

\footnotetext{
95 WALD, Arnoldo, COSTA, José Augusto Fontoura e VIEIRA, Maíra de Melo, O Impacto da Convenção de Viena sobre a Compra e Venda Internacional de Mercadorias no Direito Brasileiro: Visão Geral, in. Revista de Arbitragem e Mediação, vol. 37, RT, Abr.-Jun. 2013, p. 19

${ }^{96}$ POLIDO, Fabricio Bertini Pasquot. A Convenção de Viena sobre Contratos de Compra e Venda Internacional de Mercadorias de 1980 e suas interações com o Direito Brasileiro: Encontro Marcado ou Justiça Tardia. in. Revista de Arbitragem e Mediação, vol. 43, RT, Out.-Dez. 2014, p. 256
} 
O motivo para a baixa adesão foi a maneira pouco democrática como as convenções foram elaboradas. Sem a presença de delegados de países vitais para o comércio internacional, como França e Estados Unidos, tais países decidiram não aderir às convenções, mesmo porque consideravam que algumas proposições das convenções eram contrárias a princípios contratuais fundamentais para os seus ordenamentos ${ }^{97}$.

A baixa adesão a essas convenções levou a United Nations Commission on International Trade Law ("UNCITRAL"), órgão filiado a ONU criado em 1966, a convocar delegados de diversos países após a sua instituição para, finalmente, elaborar convenção democrática que fosse capaz de garantir a adesão de grande parte dos países responsáveis pelo comércio internacional de mercadorias, fossem eles oriundos do sistema de civil law bem como de common law.

Finalmente, em $1980^{98}$, concluiu-se o texto da Convenção de Comércio Internacional de Mercadorias (CISG) ${ }^{99}$, que procurou atender aos anseios dos delegados participarantes do grupo de trabalho formado na UNCITRAL. A Convenção seguiu, então, para a aprovação interna dos países signatários. Devido à burocracia que costuma ser observada para a aprovação de uma convenção, a CISG só entrou em vigor no cenário internacional em 1988, com a adesão de 10 países, entre os quais a França e os Estados Unidos.

Gradativamente, mais países aderiram à Convenção, hoje vigente em 83 países ${ }^{100}$, regulando aproximadamente $90 \%$ do comércio internacional. A importância do estudo da CISG após a entrada em vigor no Brasil em 17 de

\footnotetext{
${ }^{97}$ SCHLECHTRIEM, Peter, BUTLER, Petra. Un Law on International Sales, Heidelberg: Springer, 2008, p. 1

${ }^{98}$ AUDIT, Bernard. Présentation de La Convention, in. DERAINS, Yves et. GHESTIN, Jacques, La Convention de Vienne sur la vente international et les Incoterms, L.G.D.J, 1990, p. 15

${ }^{99}$ GOULART, Monica Eghari, A Convenção de Viena e os Incoterms in. Doutrinas Essenciais: Direito Internacional, Org. BAPTISTA, Luiz Olavo et MAZZUOLI, Valério de Oliveira, Rio de Janeiro: RT, p. 934

100 Dados do site da UNCITRAL: http://www.uncitral.org/uncitral/en/uncitral_texts/sale_goods/1980CISG_status.html, acesso em 15.05 .15
} 
outubro de 2014 é notória, especialmente pelo pouco conhecimento que se tem no Brasil sobre o tema.

\section{2 - Estrutura e Princípios da CISG}

A árdua tarefa de elaborar um texto que fosse aceitável por nações de cultura jurídica tão distintas obrigou o grupo de trabalho formado na UNCITRAL a considerar várias emendas propostas por diversos países, congregando princípios de direito aplicáveis tanto no sistema de common law quanto no de civil law. Nesse sentido, a CISG é explícita quanto ao seu campo de atuação ${ }^{101}$, excluindo questões sensíveis, como o comércio de navios (art. 2 (e)), de eletricidade (art. 2 (f)) e bens de uso pessoal (art. 2 (a)). A CISG é aplicável, portanto, nos casos previstos no seu art. $1^{\circ}$, excluindo as hipóteses do art. $2^{\circ}$ e $3^{\circ}$.

A CISG foi formulada com a seguinte estrutura: Parte 1 - Esfera de Aplicação e Disposições Gerais; Parte 2 - Formação do Contrato; Parte 3 Regras Materiais sobre a Compra e Venda de Mercadorias e Parte 4 Disposições Finais.

Os princípios norteadores da CISG são a boa-fé e a autonomia da vontade, além da uniformidade na aplicação da Convenção. De fato, a uniformidade na aplicação da CISG consiste em um dos maiores desafios para a sua efetividade, pois as cortes nacionais tendem a interpretar os seus preceitos com base nos princípios contratuais locais ${ }^{102}$.

\footnotetext{
${ }^{101}$ Para estudo aprofundado à luz do conceito de contrato internacional, ver: SICA, Lúcia Carvalhal. A Convenção das Nações Unidas sobre Contratos de Compra e Venda Internacional de Mercadorias: Estados não signatários e a situação do Brasil, in. Revista Trimestral de Direito Civil, vol. 31, jul-set/07, Rio de Janeiro: Padma, pp.3/39

102 VIEIRA, Iacyr de Aguilar, Direito Uniforme sobre a Compra e Venda Internacional de Mercadorias - Convergências e Divergências em sua Aplicação, in. Doutrinas Essenciais: Direito Internacional, Org. BAPTISTA, Luiz Olavo et MAZZUOLI, Valério de Oliveira, Rio de Janeiro: RT, p. 494
} 
Considera-se, portanto, que o princípio da uniformidade na aplicação da Convenção deve orientar as cortes locais e os tribunais arbitrais a aplicarem as disposições da CISG despidos dos princípios contratuais nacionais, considerando o caráter transnacional do negócio. No entanto, é difícil para o julgador, sobretudo nos países que aderiram há pouco tempo à Convenção, aplicar princípios de comércio internacional, pois tal prática foge ao cotidiano de julgamentos nacionais.

Nesse sentido, cabe à doutrina e ao STJ orientar o Judiciário a agir dessa maneira, para que a CISG tenha boa aceitação no mercado brasileiro. A maior vantagem da uniformidade na aplicação da CISG é a previsibilidade que os operadores internacionais do mercado terão ao comerciarem com empresas brasileiras, fator que pode, inclusive, ser decisivo na escolha do comprador ${ }^{103}$.

Outro princípio norteador da CISG é a boa-fé objetiva ${ }^{104}$, nos mesmos termos previstos no ordenamento brasileiro nos arts. 113 e 422 do Código Civil. A adoção de tal princípio no comércio internacional é elogiada em virtude da proteção que confere aos comerciantes de que um padrão ético de conduta deverá ser adotado pelas partes, garantindo a exigência de um comportamento leal e coerente.

\footnotetext{
"A adoção do princípio da boa-fé aos contratos internacionais de compra e venda de mercadorias afigura-se de grande valia para o fortalecimento das relações comerciais internacionais. Isso porque, além de implementar um regramento uniforme, os contratantes ainda contam com a proteção conferida pela necessidade de observação da boa-fé objetiva, que exige das partes atuação leal e coerente." 105
}

\footnotetext{
103 GAMA E SOUZA JR, Lauro A Convenção de Viena Sobre a Compra e Venda Internacional de Mercadorias - 1980 - Essa Grande Desconhecida, in. Doutrinas Essenciais: Direito Internacional, Org. BAPTISTA, Luiz Olavo et MAZZUOLI, Valério de Oliveira, Rio de Janeiro: RT, p. 721

${ }^{104}$ ROWE, Michael Convenção das Nações Unidas, in. Doutrinas Essenciais: Direito Internacional, Org. BAPTISTA, Luiz Olavo et MAZZUOLI, Valério de Oliveira, Rio de Janeiro: RT, pp. 883/884

105 BASÍllO, Ana Tereza. Aplicação e Interpretação da Convenção de Viena sob a Perspectiva do Direito Brasileiro, in. Revista de Arbitragem e Mediação, vol. 37, RT, Abr.-Jun. 2013, p. 19
} 
Há, portanto, convergência na utilização do princípio da boa-fé objetiva entre o ordenamento brasileiro e a CISG, o que deverá levar à sua aplicação sem maiores sobressaltos pelo Judiciário brasileiro. O mesmo se aplica ao princípio da autonomia da vontade, norteador da convenção e do ordenamento jurídico pátrio, que deve ser aplicado em toda sua acepção.

Em suma, os princípios norteadores da CISG não são antinômicos com as normas de direito brasileiro. Há, no entanto, algumas regulações específicas da CISG que conflitam com o tratamento conferido ao tema pelo direito brasileiro, às quais o aplicador do direito deve atentar. Entre elas, encontra-se o método de declarar resolvido o contrato (na ausência de cláusula resolutiva expressa), tema deste trabalho. A CISG filia-se ao sistema alemão, enquanto o Brasil utiliza o sistema francês. Passa-se a analisar, portanto, as hipóteses de resolução do contrato previstas na CISG.

\section{3 - Resolução de Contratos na CISG}

De forma ainda mais acentuada do que no direito brasileiro, a CISG coloca a resolução dos contratos como a ultima ratio ${ }^{106}$ em caso de inadimplemento contratual ${ }^{107}$. Busca-se privilegiar o princípio da conservação dos contratos, pois o desfazimento de uma relação obrigacional, sobretudo considerando o caráter transnacional do negócio desconstituído, é extremamente penoso para as partes e grave para o comércio internacional, pois torna sem efeito a relação econômica entre as partes, causando prejuízo para uma multiplicidade de agentes ${ }^{108}$.

\footnotetext{
106 HONNOLD, John O., Uniform Law for International Sales under the 1980 United Nations Convention, 3rd ed. (1999), pages 204-212, Kluwer Law International, Hague

${ }^{107}$ Ferrari, Franco. Fundamental Breach of Contract Under the UN Sales Convention: 25 Years of Article 25 CISG, [2006] 25 Journal of Law and Commerce 2, pp. 490/491

${ }^{108}$ Will, Micahel. in Bianca-Bonell Commentary on the International Sales Law, Giuffrè: Milão (1987) 359-367
} 
As hipóteses de resolução contratual por inadimplemento do comprador, em contratos em que a CISG é aplicável, estão previstas no art. 49 (1) da Convenção, abaixo reproduzido:

(1) The buyer may declare the contract avoided:

(a) if the failure by the seller to perform any of his obligations under the contract or this Convention amounts to a fundamental breach of contract; or

(b) in case of non-delivery, if the seller does not deliver the goods within the additional period of time fixed by the buyer in accordance with paragraph (1) of article 47 or declares that he will not deliver within the period so fixed.

Percebe-se, portanto, que há duas hipóteses de resolução contratual por inadimplemento do comprador admitidas pela CISG. Na primeira, deverá haver um inadimplemento fundamental por uma das partes. A segunda ocorre nas ocasiões em que, após o prazo adicional conferido à parte inadimplente ${ }^{109}$ (Nachfrist), o vício no cumprimento não é sanado ${ }^{110}$. Nessas ocasiões, ocorre um "agravamento" da mora, o que acarreta um inadimplemento fundamental ${ }^{111}$.

Para que se entenda as hipóteses de aplicação do primeiro caso, deve-se analisar o conceito de inadimplemento fundamental ${ }^{112}$, propositadamente vago, para que possa abarcar diferentes situações que ocorrem no âmbito do comércio internacional.

São requisitos para o inadimplemento fundamental, segundo o art. 25 da $\mathrm{CISG}^{113}$, que a falta da parte cause detrimento que substancialmente prive a

\footnotetext{
1092012 UNCITRAL Digest of case law on the United Nations Convention on the International Sale of Goods, Digesto f Article 25, available at: http://www.cisg.law.pace.edu/cisg/text/digest-2012-25.html.

110 HONNOLD, John O., Uniform Law for International Sales under the 1980 United Nations Convention, 3rd ed. (1999), pages 325-334, Kluwer Law International, Hague

${ }^{111}$ SCHLECHTRIEM, Peter, BUTLER, Petra. Un Law on International Sales, Heidelberg: Springer, 2008, p. 93

112 SCHLECHTRIEM, Peter, BUTLER, Petra. Un Law on International Sales, Heidelberg: Springer, 2008, p. 98

113 “Art. 25: A violação ao contrato por uma das partes é considerada como essencial se causar à outra parte prejuízo de tal monta que substancialmente a prive do resultado que poderia esperar do contrato, salvo se a parte infratora não tiver previsto e uma pessoa razoável da mesma condição e nas mesmas circunstâncias não pudesse prever tal resultado."
} 
contraparte daquilo que seria previsível e legítimo se esperar do contrato ${ }^{114}$. O resultado desse descumprimento deve ser, ainda, previsível ${ }^{115}$ para a parte inadimplente ou, ao menos, para uma pessoa razoável que atue no mesmo ramo. Percebe-se, portanto, que o artigo exige um alto grau de comprometimento do interesse em manter o contrato para admitir a sua resolução, assemelhando-se, nesse particular ao conceito do art. 395, parágrafo único do Código Civil ${ }^{116}$. A CISG procura manter os contratos internacionais em que é aplicável hígidos, admitindo a resolução apenas em situações extremas $^{117}$. Para que seja possível a resolução contratual, o inadimplemento deve ter causado enorme dano à economia do contrato ${ }^{118}$.

Não há qualquer distinção, ainda, entre a violação de uma obrigação fundamental ou acessória ao contrato, importando a análise sobre a superveniência da utilidade do contrato para a parte lesada ${ }^{119}$. Se, economicamente, ainda houver vantagem para o lesado em manter o contrato, deve se optar pela sua manutenção. No entanto, não se deve exigir um esforço desmedido, capaz de prejudicar o lesado, adotando-se a razoabilidade como princípio norteador.

O conceito de inadimplemento fundamental, como se vê, é aberto, cabendo à doutrina e jurisprudência cunhar o seu real significado. Não deve haver, no entanto, grande dificuldade na aplicação desse instituto no Brasil,

\footnotetext{
114 TIBURCIO, Carmen. Algumas Notas sobre a CISG, sua Incorporação e Status no Direito Brasileiro in. Revista de Direito Bancário e do Mercado de Capitais, jul/ago/set 2014, Rio de Janeiro: RT, p. 76

115 CHENGWEI, Liu: THE CONCEPT OF FUNDAMENTAL BREACH: Perspectives from the CISG, UNIDROIT Principles and PECL and case law, available at: http://www.cisg.law.pace.edu/cisg/biblio/liu8.html.

116 AGUIAR JÚNIOR, Ruy Rosado de. A Convenção de Viena e a resolução do contrato por incumprimento. Revista de Informação Legislativa, $\mathrm{n}^{\circ}$ 121, jan/mar/94, Brasília: Senado Federal, p. 215

${ }^{117}$ GREBLER, Eduardo. A Convenção das Nacões Unidas sobre Contratos de Venda Internacional de Mercadorias e o Comércio Internacional Brasileiro, in. Revista de Direito Mercantil, Industrial, Econômico e Financeiro, vol. 144, São Paulo: Malheiros, out/nov/dez 2006, p. 69

118 REsp 272.739/MG, Rel. Ministro RUY ROSADO DE AGUIAR, QUARTA TURMA, julgado em 01/03/2001, DJ 02/04/2001

${ }^{119}$ AGUIAR JÚNIOR, Ruy Rosado de. A Convenção de Viena e a resolução do contrato por incumprimento. Revista de Informação Legislativa, $\mathrm{n}^{\circ}$ 121, jan/mar/94, Brasília: Senado Federal, p. 214
} 
devido à semelhança com o conceito de inadimplemento qualificado estudado acima, largamente aceito pela doutrina e jurisprudência nacionais. Para tanto, basta que se aplique o princípio da utilidade na prestação, tal como previsto no art. 395, parágrafo único do Código Civil.

O segundo caso de inadimplemento que pode ensejar a resolução do contrato é o atraso na realização da prestação após a concessão de prazo suplementar, nos termos do art. 49 (1) (b) da Convenção ${ }^{120}$.

O objetivo da regulação expressa dessa hipótese é de evitar a resolução dos contratos em caso de entrega da mercadoria, mesmo que com atraso. A pontualidade, no caso, não deverá ser essencial para o contrato, caso contrário, a simples mora será considerada inadimplemento.

Sobre o referido tema, foi emitida a opinião $\mathrm{n}^{\mathrm{o}} 5$ pelo Conselho Consultivo da Convenção de Viena sobre Compra e Venda Internacional de Mercadorias (Cisg Advisory Council) ${ }^{121}$, que foi criado pelo Instituto de Direito Comercial Internacional da Pace University School of Law.

A opinião, conquanto não tenha valor legal, é largamente utilizada na fundamentação de diversas decisões ao redor do mundo. Nesse caso, o Conselho Consultivo da CISG, reafirmando a preocupação em dificultar a resolução dos contratos, emitiu parecer fazendo diversas considerações sobre o caso de entrega das mercadorias, considerando a interpretação sistemática do contrato para estabelecer a possibilidade de aferir inadimplemento fundamental. Foi considerada, ainda, a hipótese de vício na documentação que acompanha a mercadoria, que pode causar, dependendo da situação, a perda da utilidade dos bens comerciados.

De tudo, conclui-se que a hipótese de atraso na entrega das mercadorias, se aplicado o sistema do Nachfrist, torna o inadimplemento capaz de resolver o

\footnotetext{
120 Nachfrist significa "após o prazo" em alemão (Nach = após e Frist = prazo).

${ }^{121}$ CISG Advisory Council, Revista Brasileira de Arbitragem, vol. 23, São Paulo: IOB, jul/ago/set 2009, pp. $227 / 239$
} 
contrato, apesar de a mora, por si, não ser causa de inadimplemento fundamental. Nesse sentido, a simples expiração do prazo concedido não é causa de resolução do contrato, pois a parte adimplente pode conceder prazo adicional.

A resolução pode ser declarada, também, pelo vendedor, em caso de descumprimento do prazo adicional concedido para o pagamento pela mercadoria entregue.

Vistas as possibilidades de resolução do contrato na CISG, cumpre-se verificar como tal resolução é reconhecida e os seus efeitos para as partes

\subsection{4 - A Declaração de Resolução e os Efeitos para as Partes}

O sistema de resolução contratual na CISG difere do sistema geral de resolução contratual brasileiro, pois filia-se ao sistema alemão ${ }^{122}$. Nesse sentido, a declaração de resolução contratual, ainda que por motivo não expressamente previsto no contrato, é extrajudicial ${ }^{123}$, operando-se por mera comunicação à parte inadimplente (art. 26) ${ }^{124}$.

Basta, portanto, que a mensagem seja enviada ao inadimplente. A CISG confere ao inadimplente o risco pelo não recebimento da mensagem, desde que o seu envio tenha sido feito por meio usual aos olhos de um homem médio na mesma situação. Tal diferença, aparentemente incompatível com o direito brasileiro, pode ser resolvida pelos critérios de cronologia e especialidade, aplicando-se a CISG aos casos especificados em seu art. $1^{\circ}$, desde que o fato tenha ocorrido após a adesão do Brasil à convenção.

\footnotetext{
1222012 UNCITRAL Digest of case law on the United Nations Convention on the International Sale of Goods - Digest of Article 49 - available at: http://www.cisg.law.pace.edu/cisg/text/digest-2012-49.html. 123 TRIPODI, Leandro. Aspectos da Tutela à Boa-Fé na Convenção de Viena sobre a Compra e Venda Internacional de Mercadorias, in. Arbitragem e Comércio Internacional, Coord. CELLI JUNIOR, Umberto, BASSO, Maristella, AMARAL JÚNIOR, Alberto do, São Paulo: Quartier Latin, p. 398

${ }^{124}$ SCHLECHTRIEM, Peter, BUTLER, Petra. Un Law on International Sales, Heidelberg: Springer, 2008, p. 94
} 
Portanto, a declaração unilateral de resolução pode, perfeitamente, ser aplicada no direito brasileiro, nos casos específicos de aplicação da CISG ${ }^{125}$.

A CISG não determinou a forma e o conteúdo dessa declaração. A doutrina e a jurisprudência, no entanto, têm afirmado que a declaração não depende de forma específica, em virtude do princípio da liberdade das formas (arts. 11 e 29). O conteúdo da declaração também não está sujeito a regras estritas, sendo tal mensagem interpretada à luz dos critérios previstos no art. $8^{\circ}$ da Convenção. Nesse sentido, afirmou Daniel Gruenbaum:

\begin{abstract}
"A declaração de resolução deve ser suficientemente clara a respeito da intenção do credor em pôr fim ao contrato. Não há, porém, conteúdo pré-determinado, tampouco é necessário empregar o termo resolução. A declaração deve ser interpretada à luz dos critérios do art. 8 e, no caso de dúvida sobre a intenção do credor com sua declaração (art. 8 (1)), deve-se analisar se uma pessoa razoável na posição do devedor (art. 8 (2)) teria entendido que o credor, com sua declaração, quis pôr fim ao contrato. Em especial, devem ser consideradas todas as circunstâncias relevantes do caso, incluindo as negociações, práticas estabelecidas entre as partes, usos a que estejam vinculadas e qualquer conduta subsequente (art. 8 (3))." ${ }^{, 126}$
\end{abstract}

Questão mais polêmica é o prazo para a emissão da declaração, pois há variação conforme as circunstâncias do negócio. Em regra, a declaração pode ser feita até que ocorra a decadência desse direito, segundo o ordenamento nacional aplicável. No entanto, o prazo é diferenciado em três situações.

Na hipótese de a mercadoria solicitada já ter sido entregue (art. 49 (2)), a CISG expressamente afirma que a declaração deverá ser feita em um prazo razoável, sob pena de perda do direito à resolução. Esse prazo dependerá das circunstâncias do negócio, devendo ser aferido caso a caso conforme a prática estabelecida pelas partes. O mesmo se aplica na resolução requerida pelo vendedor, caso o comprador já tenha pago o preço integral e venha a descumprir outra obrigação prevista no contrato.

\footnotetext{
125 Há, inclusive, no ordenamento brasileiro, outra hipótese de resolução extrajudicial mesmo sem cláusula resolutória expressa. Trata-se da norma prevista no art. 32 da Lei 6.766/79, que trata do parcelamento do solo urbano.

${ }^{126}$ GRUENBAUM, Daniel. Resolução do Contrato e Avoidance na CISG, in. Revista de Arbitragem e Mediação, vol. 37, RT, Abr.-Jun. 2013, pp. 95/96
} 
Há, ainda, o caso de resolução contratual em caso de compra e venda com entrega diferida das mercadorias. Em regra, caso haja violação essencial, a parte adimplente poderá requerer a resolução parcial do contrato em relação à prestação em aberto. No entanto, caso as circunstâncias sejam claras a ensejar a perda na confiança no adimplemento das prestações futuras, faculta-se a resolução integral do contrato com efeitos ex nunc (art. 73 (2)). Trata-se, portanto, de caso especial de inadimplemento anterior ao termo na CISG. Para exercer essa prerrogativa, no entanto, a parte adimplemento deve emitir a declaração de resolução em um prazo razoável, sob pena de perda do direito.

Deve se atentar, ainda, que tal cláusula deve ser interpretada à luz do princípio geral de boa-fé, previsto no art. 7(1) da CISG. Nesse sentido, o credor também perderá o direito à resolução caso "se mantivesse inerte por certo tempo após o descumprimento e criasse no devedor a crença de que não exerceria tal direito"127.

A resolução gera para as partes, ainda, o efeito liberatório e restitutório das prestações, tal como no direito civil brasileiro.

Diante de tudo isso, percebe-se que o sistema previsto na CISG privilegia os princípios da conservação dos contratos e da boa-fé. Dessa maneira, busca promover o comércio internacional e sancionar condutas antiéticas, de modo a garantir maior facilidade para o tráfico e os comerciantes em geral.

127 GRUENBAUM, Daniel. Resolução do Contrato e Avoidance na CISG, in. Revista de Arbitragem e Mediação, vol. 37, RT, Abr.-Jun. 2013, pp. 100 


\section{Conclusão}

A presente monografia teve como foco analisar os contornos do instituto da resolução de contratos no direito brasileiro. Conforme exposto, a utilização desmedida do referido instituto pode causar graves problemas para a economia, razão pela qual a doutrina e a jurisprudência o interpretam à luz dos princípios contratuais presentes no Código Civil de 2002, notadamente a função social dos contratos e a boa-fé objetiva.

A partir de uma visão histórica do instituto, buscou-se entender os fundamentos utilizados pelos seus criadores e as impropriedades que a errônea interpretação dos textos medievais acarretou na formulação dos Código Civis vigentes na época contemporânea. Em seguida, foram estudados os sistemas 
previstos no Código Napoleão e no $\mathrm{BGB}$, com uma breve exposição das respectivas vantagens e desvantagens.

Ainda, buscou-se delimitar a correta terminologia da expressão "resolução", pois a tradução equivocada de livros estrangeiros levou a uma impropriedade terminológica interminável na doutrina brasileira, causando enorme confusão inclusive no legislador do Código Civil vigente.

Nesse sentido, os mecanismos limitadores à utilização do instituto da resolução devem ser analisados com cuidado, a fim de que os contratos sejam extintos apenas nos casos em que o inadimplemento for de tal monta que a sua manutenção será mais gravosa para o credor do que a sua execução parcial ou de uma maneira alternativa.

Reforçando esse entendimento, analisou-se os contornos do instituto da resolução contratual à luz da CISG, incorporada ao direito brasileiro em outubro de 2014. Verificou-se que as suas disposições são compatíveis com o direito brasileiro, reforçando a ideia da manutenção do contrato como princípio norteador de interpretação em caso de tentativa de extinção contratual por uma das partes.

Por tudo o que foi exposto, conclui-se que, a despeito do art. 475 do CC conferir à parte lesada a possibilidade incondicionada de requerer a resolução contratual em caso de inadimplemento da contraparte, tal hipótese só é possível em caso de inadimplemento qualificado, devendo-se limitar o seu âmbito de aplicação para os casos em que, efetivamente, o contrato perdeu o seu proveito econômico. 


\section{Bibliografia}

AGUIAR JÚNIOR, Ruy Rosado de. A Convenção de Viena e a resolução do contrato por incumprimento. Revista de Informação Legislativa, $\mathrm{n}^{\mathbf{o}} 121$, jan/mar/94, Brasília: Senado Federal

. Extinção dos contratos por incumprimento

do devedor: resolução: de acordo com o novo Código civil. $2^{\mathrm{a}}$ ed. Rio de Janeiro: AIDE, 2003

ALMEIDA COSTA, Mário Júlio de. Direito das Obrigações, $8^{\text {a }}$ ed. Coimbra: Almedina, 2000.

ALVES, João Luiz. Código Civil da República dos Estados Unidos do Brasil, $3^{\mathrm{a} e d .}$ Rio de Janeiro: Borsoi, 1958

ALVIM, Agostinho, Da Inexecução das Obrigações e suas Consequências, $3^{\mathrm{a}}$ ed. Rio de Janeiro: Livraria Legislação Brasileira, 1965

ASSIS, Araken de. Resolução do Contrato por Inadimplemento, $4^{\mathrm{a}}$ ed. São Paulo: Revista dos Tribunais, 2004

AUDIT, Bernard. Présentation de La Convention, in. DERAINS, Yves et. GHESTIN, Jacques, La Convention de Vienne sur la vente international et les Incoterms, L.G.D.J, 1990

AZEVEDO, Antonio Junqueira de. Natureza Jurídica do contrato de consórcio. Classificação dos atos jurídicos quanto ao número de partes e quanto aos efeitos. Os contratos relacionais. Alteração das circunstâncias e onerosidade excessiva. Resolução parcial do contrato. Função social do contrato. In. Revista Trimestral de Direito Civil, vol. 21, Jan-Mar. 2005

BAPTISTA, Luiz Olavo, Lex Mercatoria, in. Arbitragem Doméstica e Internacional, Coord. FERRAZ, Rafaella e MUNIZ, Joaquim de Paiva, Rio de Janeiro: Forense, 2008

BASÍLIO, Ana Tereza. Aplicação e Interpretação da Convenção de Viena sob a Perspectiva do Direito Brasileiro, in. Revista de Arbitragem e Mediação, vol. 37, RT, Abr.-Jun. 2013

BASSO, Larissa de Santis, Contratos Transnacionais e o fundamento da arbitragem comercial internacional: um enfoque didático, in. Arbitragem 
nacional e internacional - Os novos debates e a visão dos jovens arbitralistas, Coord. MOTTA PINTO, Anna Luiza Baccarat e SKITNEVSKY, Karin Hlavnicka, Rio de Janeiro: Elsevier, 2012

BEVILAQUA, Clovis. Codigo Civil dos Estados Unidos do Brasil Commentado, $6^{\text {a }}$ ed. Rio de Janeiro: Livraria Francisco Alves, 1943, p. 254

CARVALHO SANTOS, João Manuel de. Código Civil Brasileiro Interpretado. Vol. XII 13a ed., São Paulo: Livraria Freitas Bastos, 1988

CASTRO NEVES, José Roberto de. Direito das Obrigações, $3^{\mathrm{a}} \mathrm{ed}$. Rio de Janeiro: GZ, 2012, p. 328; CHAMOUN, Ebert. Instituições de Direito Romano, $5^{\mathrm{a}}$ ed., Rio de Janeiro: Forense, 1968

CHENGWEI, Liu: THE CONCEPT OF FUNDAMENTAL BREACH: Perspectives from the CISG, UNIDROIT Principles and PECL and case law, disponível em: http://www.cisg.law.pace.edu/cisg/biblio/liu8.html.

COGO, Rodrigo Barreto. A Frustração do Fim do Contrato - O impacto dos fatos supervenientes sobre o programa contratual. Rio de Janeiro: Renovar, 2012.

COMPARATO, Fabio Konder. Notas sobre a resolução de contratos. In. Direito Empresarial, Rio de Janeiro: Saraiva, 1990, p. 380 e GOMES, Orlando. Resolução de Venda por Inutilidade da Coisa Vendida, in. Questões de Direito Civil, $5^{\text {ad}}$. Rio de Janeiro: Saraiva, 1988

COUTO E SILVA, Clovis do. A Obrigação como Processo, Editora FGV, 2006

DIREITO, Carlos Gustavo Vianna, Do Contrato - Teoria Geral. Rio de Janeiro: Renovar, 2007, p. 204.

ENNECERUS, Ludwig, KIPP, Theodor et. WOLFF, Martin. Derecho de Obligaciones, t. II, Vol. 1º, Barcelona: Bosch, 1954

FERRARI, Franco. Fundamental Breach of Contract Under the UN Sales Convention: 25 Years of Article 25 CISG, [2006] 25 Journal of Law and Commerce 2

FERREIRA DA SILVA, Jorge Cesa. Inadimplemento das Obrigações. São Paulo: RT, 2006 
FONSECA, Rodrigo Garcia da. A Função Social do Contrato e o Alcance do Artigo 421 do Código Civil. Rio de Janeiro: Renovar

FULLER, Lon L. et. EISENBERG, Melvin Aron, Basic Contract Law, St. Paul: West Group, 2001

GAMA E SOUZA JR, Lauro A Convenção de Viena Sobre a Compra e Venda Internacional de Mercadorias - 1980 - Essa Grande Desconhecida, in. Doutrinas Essenciais: Direito Internacional, Org. BAPTISTA, Luiz Olavo et MAZZUOLI, Valério de Oliveira, Rio de Janeiro

GAMA e SOUZA JR., Contratos Internacionais à luz dos Princípios do UNIDROIT 2004 - Soft Law, Arbitragem e Jurisdição. Rio de Janeiro: Renovar, 2006

GENICON, Thomas. La Résolution Du Contrato Pour Inexécution, Paris: L.G.D.J, 2007

GOMES, Orlando. Contratos. $26^{\mathrm{a}}$ ed. Rio de Janeiro: Forense, 2008 Resolução de Venda por Defeito na Qualidade da Coisa, in. Questões de Direito Civil, 5' d. Rio de Janeiro: Saraiva, 1988, p. 72

GOMES, Rogério Zuel. Teoria Contratual Contemporânea, Rio de Janeiro: Forense, 2004

GONÇALVES, Carlos Roberto. Direito Civil Brasileiro, Vol. III, 2a ed. Rio de Janeiro: Saraiva, 2006

GOULART, Monica Eghari, A Convenção de Viena e os Incoterms in. Doutrinas Essenciais: Direito Internacional, Org. BAPTISTA, Luiz Olavo et MAZZUOLI, Valério de Oliveira, Rio de Janeiro: RT

GRAND, Julio Conte, La Extinción de La Relación Contractual, in. Contratos Civiles y Comerciales, Coord. TARTIÈRE, Gabriel de Reina., Buenos Aires: Heliasta, 2010

GREBLER, Eduardo. A Convenção das Nacões Unidas sobre Contratos de Venda Internacional de Mercadorias e o Comércio Internacional Brasileiro, in. Revista de Direito Mercantil, Industrial, Econômico e Financeiro, vol. 144, São Paulo: Malheiros, out/nov/dez 2006 
GRUENBAUM, Daniel. Resolução do Contrato e Avoidance na CISG, in. Revista de Arbitragem e Mediação, vol. 37, RT, Abr.-Jun. 2013

HONNOLD, John O., Uniform Law for International Sales under the 1980 United Nations Convention, 3rd ed. (1999), pages 204-212, Kluwer Law International, Hague

KONDER, Carlos Nelson e RENTERÍA, Pablo. A funcionalização das relações obrigacionais: interesse do credor e patrimonialidade da prestação. In. Diálogos sobre Direito Civil, Vol. II, TEPEDINO, Gustavo e FACHIN, Luiz Edson. Rio de Janeiro: Renovar, 2008

LARENZ, Karl. Derecho de Obligaciones, , Madri: Revista de Derecho Privado - Editorial, 1958

LIMA, Clarissa Costa Reflexões sobre a resolução do contrato na nova teoria contratual, in. A Nova Crise do Contrato - Estudos sobre a Nova Teoria Contratual - coord. Claudia Lima Marques - São Paulo: RT, 2007

LORENZETTI, Ricardo Luis. Tratado de Los Contratos - Parte General. $2^{\mathrm{a}} \mathrm{ed}$., Buenos Aires: Rubinzal - Culzoni Editores, 2010

LOUREIRO, Francisco Eduardo. Extinção dos Contratos, in. Teoria Geral dos Contratos, São Paulo: Atlas, 2011, p. 610, coord. LOTUFO, Renan e NANNI, Giovanni Ettore

LOVECE, Graciela et GHERSI, Carlos A., Derecho Económico, Buenos Aires: Errepar, 2013

MARINO, FRANCISCO: A Interpretação do Negócio Jurídico. São Paulo: Saraiva, 2011

MAXIMILIANO, Carlos. Hermenêutica e Aplicação do Direito, $6^{\mathrm{a}}$ ed., Rio de Janeiro: Forense, 1979

MECHELANY VELOSO, Silvia. Análise Econômica e Função Social dos Contratos - art. 421 do Código Civil. in. Revista de Direito Privado, vol. 54, Abril-Junho 2013, RT.

MOREIRA ALVES, José Carlos. Direito Romano, $13^{\mathrm{a}}$ ed., Rio de Janeiro: Forense, 2005 
NEGREIROS, Teresa. Teoria do Contrato - Novos Paradigmas, Rio de Janeiro: Renovar, 2002

PEREIRA, Caio Mário da Silva, Instituições de Direito Civil, Vol. III, $17^{\mathrm{a}}$ ed., Rio de Janeiro: Forense, 2012

PERILlO, Joseph, Calamari and Perillo on Contracts, $5^{\mathrm{a}}$ ed., St. Paul: Thomson/West

PLANIOL, Marcel, Traité Élémentaire de Droit Civil, t. XII, Paris: Librairie Générale de Droit \& de Jurisprudence, 1909

POLIDO, Fabricio Bertini Pasquot. A Convenção de Viena sobre Contratos de Compra e Venda Internacional de Mercadorias de 1980 e suas interações com o Direito Brasileiro: Encontro Marcado ou Justiça Tardia. in. Revista de Arbitragem e Mediação, vol. 43, RT, Out.-Dez. 2014

RIPERT, Georges et. PLANIOL, Marcel. Traité Pratique de Droit Civil Français, t. VI, Paris: Librairie Générale de Droit et de Jurisprudence, 1952

RIZZARDO, Arnaldo. Contratos, $6^{\mathrm{a} e d .,}$ Rio de Janeiro: Forense, 2006

ROPPO, Enzo. O Contrato, Coimbra: Livraria Almedina, 1978

ROWE, Michael Convenção das Nações Unidas, in. Doutrinas Essenciais: Direito Internacional, Org. BAPTISTA, Luiz Olavo et MAZZUOLI, Valério de Oliveira, Rio de Janeiro: RT

SCHLECHTRIEM, Peter, BUTLER, Petra. Un Law on International Sales, Heidelberg: Springer, 2008

SCHREIBER, Anderson. A triplíce transformação do adimplemento: Adimplemento substancial, inadimplemento antecipado e outras figuras. In: Revista Trimestral de Direito Civil, vol. 32, Out-Dez. 2007

SCHWAB, Dieter et. LÖHNIG, Martin, Einführung in das Zivilrecht, Heidelberg: C.F. Müller, 2012

SERPA LOPES, Miguel Maria de. Curso de Direito Civil, Vol. III, $6^{\mathrm{a}}$ ed., Rio de Janeiro: Livraria Freitas Bastos, 1966, pp. 202/203. A crítica é de Pontes de Miranda. Tratado de Direito Privado. $4^{a}$ ed., São Paulo: Borsoi, 1959. t. 25 
SICA, Lúcia Carvalhal. A Convenção das Nações Unidas sobre Contratos de Compra e Venda Internacional de Mercadorias: Estados não signatários e a situação do Brasil, in. Revista Trimestral de Direito Civil, vol. 31, jul-set/07, Rio de Janeiro: Padma

TEPEDINO, Gustavo: Notas sobre a função social dos contratos. In. O Direito \& o Tempo, Org. TEPEDINO, Gustavo e FACHIN, Luiz Edson. Rio de Janeiro: Renovar, 2008, pp. 395/405

TEPEDINO, Gustavo; BARBOZA, Heloisa Helena; BODIN DE MORAES, Maria Celina, org. Código Civil Interpretado Conforme a Constituição da República. Rio de Janeiro: Renovar, 2012

THEODORO JÚNIOR, Humberto, Comentários ao novo Código Civil, volume 3, t. 1: livro III - dos fatos jurídicos: do negócio jurídico. - Rio de Janeiro: Forense, 2003

THEODORO JÚNIOR, Humberto. O Contrato e sua Função Social. $2^{\mathrm{a} e d . ~ R i o ~}$ de Janeiro: Forense, 2004

TIBURCIO, Carmen. Algumas Notas sobre a CISG, sua Incorporação e Status no Direito Brasileiro in. Revista de Direito Bancário e do Mercado de Capitais, jul/ago/set 2014, Rio de Janeiro: RT

TIMM, Luciano Benetti. Direito, Economia e a Função Social do Contrato. In. Função Social do Direito. Coord. TIMM, Luciano Benetti e MACHADO, Rafael Bicca. São Paulo: Quartier Latin, 2009

TRIPODI, Leandro. Aspectos da Tutela à Boa-Fé na Convenção de Viena sobre a Compra e Venda Internacional de Mercadorias, in. Arbitragem e Comércio Internacional, Coord. CELLI JUNIOR, Umberto, BASSO, Maristella e AMARAL JÚNIOR, Alberto do, São Paulo: Quartier Latin, p. 398

VARELA, Antunes. Das Obrigações em Geral. $2^{\mathrm{a}}$ ed. Coimbra: Almedina, 1974

VIEIRA, Iacyr de Aguilar, Direito Uniforme sobre a Compra e Venda Internacional de Mercadorias - Convergências e Divergências em sua Aplicação, in. Doutrinas Essenciais: Direito Internacional, Org. BAPTISTA, Luiz Olavo et MAZZUOLI, Valério de Oliveira, Rio de Janeiro: RT

WALD, Arnoldo, COSTA; José Augusto Fontoura; VIEIRA, Maíra de Melo, $O$ Impacto da Convenção de Viena sobre a Compra e Venda Internacional de 
Mercadorias no Direito Brasileiro: Visão Geral, in. Revista de Arbitragem e Mediação, vol. 37, RT, Abr.-Jun. 2013

WALD, Arnoldo. Obrigações e Contratos. 17ª ed., Rio de Janeiro: Saraiva, 2006

WILL, Michael. in Bianca-Bonell Commentary on the International Sales Law, Milão: Giuffrè, 1987

\section{Jurisprudência}

REsp 1286144/MG, Rel. Ministro PAULO DE TARSO SANSEVERINO, TERCEIRA TURMA, julgado em 07/03/2013, DJe 01/04/2013

REsp 22.830/RJ, Rel. Ministro SÁlVIO DE FIGUEIREDO TEIXEIRA, QUARTA TURMA, julgado em 15/06/1992, DJ 17/08/1992

REsp 272.739/MG, Rel. Ministro RUY ROSADO DE AGUIAR, QUARTA TURMA, julgado em 01/03/2001, DJ 02/04/2001

REsp 76.362/MT, Rel. Ministro RUY ROSADO DE AGUIAR, QUARTA Turma, julgado em 11/12/1995, DJ 01.04.96

TJ/SP - AP 0039044-20.2010.8.26.0602, Rel. Des. Milton CARVAlho, $4^{\mathrm{a}}$ Câmara de Direito Privado, j. em 27.03.14, DJ 03.04.14

\section{Outros}

Lista de países signatários. Disponível em:

http://www.uncitral.org/uncitral/en/uncitral_texts/sale_goods/1980CISG_status html. Acesso em 15 mar. 2015.

Informações do site: http://www.newadvent.org/cathen/07527a.htm- acesso em 14.05.15. Acesso em 15 mar. 2015.

2012 UNCITRAL Digest of case law on the United Nations Convention on the International Sale of Goods, Digest of Article 25, disponível em: http://www.cisg.law.pace.edu/cisg/text/digest-2012-25.html. Acesso em 15 mar. 2015. 
2012 UNCITRAL Digest of case law on the United Nations Convention on the International Sale of Goods - Digest of Article 49 - disponível em: http://www.cisg.law.pace.edu/cisg/text/digest-2012-49.html. Acesso em 15 mar. 2015.

CISG Advisory Council, Revista Brasileira de Arbitragem, vol. 23, São Paulo: IOB, jul/ago/set 2009 